\title{
Heliotropium indicum L.: From Farm to a Source of Bioactive Compounds with Therapeutic Activity
}

\author{
Chandan Sarkar, ${ }^{1}$ Milon Mondal, ${ }^{1}$ Bilkis Khanom, ${ }^{1}$ Md. Monir Hossain, ${ }^{2}$ \\ Md. Solayman Hossain, ${ }^{1}$ Antoni Sureda, ${ }^{3}$ Muhammad Torequl Islam (D), \\ Miquel Martorell $\mathbb{D D}^{4,5}$ Manoj Kumar, ${ }^{6}$ Javad Sharifi-Rad $\mathbb{D}^{7,8}$ Ahmed Al-Harrasi, ${ }^{7}$ \\ and Ahmed Al-Rawahi ${ }^{9}$ \\ ${ }^{1}$ Department of Pharmacy, Bangabandhu Sheikh Mujibur Rahman Science and Technology University, \\ Gopalganj 8100, Bangladesh \\ ${ }^{2}$ Department of Pharmacy, Mawlana Bhashani Science and Technology University, Tangail 1902, Bangladesh \\ ${ }^{3}$ Research Group in Community Nutrition and Oxidative Stress, University of Balearic Islands, \\ Health Research Institute of Balearic Islands (IdISBa), and CIBEROBN (Physiopathology of Obesity and Nutrition), \\ E-07122 Palma, Balearic Islands, Spain \\ ${ }^{4}$ Department of Nutrition and Dietetics, Faculty of Pharmacy, and Centre for Healthy Living, University of Concepción, \\ Concepción, Chile \\ ${ }^{5}$ Universidad de Concepción, Unidad de Desarrollo Tecnológico, UDT, Concepción, Chile \\ ${ }^{6}$ Chemical and Biochemical Processing Division, ICAR-Central Institute for Research on Cotton Technology, \\ Mumbai 400019, India \\ ${ }^{7}$ Phytochemistry Research Center, Shahid Beheshti University of Medical Sciences, Tehran, Iran \\ ${ }^{8}$ Facultad de Medicina, Universidad del Azuay, Cuenca, Ecuador \\ ${ }^{9}$ Natural and Medical Sciences Research Centre, University of Nizwa, Birkat Almouz 616, Oman
}

Correspondence should be addressed to Muhammad Torequl Islam; dmt.islam@bsmrstu.edu.bd, Miquel Martorell; martorellpons@gmail.com, and Javad Sharifi-Rad; javad.sharifirad@gmail.com

Received 5 March 2021; Accepted 11 May 2021; Published 1 June 2021

Academic Editor: Ihsan Ul Haq

Copyright (c) 2021 Chandan Sarkar et al. This is an open access article distributed under the Creative Commons Attribution License, which permits unrestricted use, distribution, and reproduction in any medium, provided the original work is properly cited.

This study aimed to summarize the available data on the ethnomedicinal and phytopharmacological activities of Heliotropium indicum L. based on database reports. For this purpose, an up-to-date literature search was carried out in the Google Scholar, Scopus, Springer Link, Web of Science, ScienceDirect, ResearchGate, PubMed, Chem Spider, Elsevier, BioMed Central, and patent offices (e.g., USPTO, CIPO, NPI, Google patents, and Espacenet) for the published materials. The findings suggest that the plant contains many important phytochemicals, including pyrrolizidine alkaloids, indicine, echinitine, supinine, heleurine, heliotrine, lasiocarpine, acetyl indicine, indicinine, indicine $\mathrm{N}$-oxide, cynoglossine, europine $\mathrm{N}$-oxide, heleurine $\mathrm{N}$-oxide, heliotridine $\mathrm{N}$ oxide, heliotrine $\mathrm{N}$-oxide, heliotrine, volatile oils, triterpenes, amines, and sterols. Scientific reports revealed that the herb showed antioxidant, analgesic, antimicrobial, anticancer, antituberculosis, antiplasmodial, anticataract, antifertility, wound healing, antiinflammatory, antinociceptive, antihyperglycemic, anthelmintic, diuretic, antitussive, antiglaucoma, antiallergic, and larvicidal activity. In conclusion, in vitro studies with animal models seem to show the potential beneficial effects of $H$. indicum against a wide variety of disorders and as a source of phytotherapeutic compounds. However, clinical studies are necessary to confirm the effects observed in animal models, determine the toxicity of the therapeutic dose and isolate the truly bioactive components. 


\section{Introduction}

One of the barebones for the victory of principal health care is the accessibility and use of apposite drugs. Traditional medicine, since the early formation of human civilization, has been the most sensible and affordable source of treatment in the health care system, which is why people continue to rely on plants for multiple disorders [1]. The medicinal uses of each plant derive from the presence of significant amounts of various natural products, which can be used as alternative therapeutic or adjuvant tools. Medicinal plants play an energetic role in the discovery of new therapeutic agents, thus growing interest in the use of pharmaceutical consumption [2,3]. Medicinal plants contain many constituents such as alkaloids, flavonoids, tannins, phenols, saponins, and glycosides, with notable biological activities such as antimicrobial, analgesic, antipyretic, antitumor, wound healing, and cardioprotective, among others that can be useful against diverse human diseases [4,5].

Heliotropium indicum L. (family: Boraginaceae; Figure 1), locally known as "Hatisur" is derived from the Greek words "helios" meaning "sun" and "tropein" meaning "to turn," indicating that the flowers and leaves turn toward the sun and known as the "Indian turnsole" [6]. It is also known as Eliopia riparia Raf., Eliopia serrata Raf., Heliophytum indicum (L.) DC., Heliotropium africanum Schumach. \& Thonn., Heliotropium cordifolium Moench, Heliotropium foetidum Salisb., Heliotropium horminifolium Mill., and Tiaridium indicum (L.) Lehm. H. indicum is distributed throughout Bangladesh, Nepal, Sri Lanka, Thailand, India, and other areas of tropical Asia and in some parts of Africa [7]. H. indicum is a small annual or perennial herb with a height of about $15-50 \mathrm{~cm}$ in length, with the leaves always opposite, and the stem and root covered by a hairy layer [7]. Flowering time is around the whole year, and flowers are calyx green; the fruits are dried and consist of 2-4 free or almost free nutlets in $4-5 \mathrm{~mm}$ long [8].

Traditionally, this plant is widely used against many pathological disorders including wound healing, antidote, bone fracture, febrifuge, cures eye infection, menstrual disorder, nerve disorder, kidney problem, and antiseptic purpose [9-14]. H. indicum contains many important phytochemicals such as tannins, saponins, steroids, oils, and glycosides [12,15]. Schoental [16] and Hartmann and Ober [17] isolated pyrrolizidine alkaloids (e.g., indicine $N$-oxide, heliotrine, etc.) from this plant. Scientific reports suggest that $H$. indicum possesses many important pharmacological activities, including antiinflammatory [18], wound-healing [19], anticancer [15], and anticataract activities [20].

This review aims to show the current scenario on the ethnomedicinal, phytochemical, and pharmacological profiles of $H$. indicum.

\section{Plant Taxonomy}

The taxonomic hierarchy of $H$. indicum is the following:

$$
\begin{aligned}
& \text { Domain: Eukaryota } \\
& \text { Kingdom: Plantae }
\end{aligned}
$$

\author{
Phylum: Spermatophyta \\ Subphylum: Angiospermae \\ Class: Dicotyledonae \\ Order: Boraginales \\ Family: Boraginaceae \\ Genus: Heliotropium \\ Species: Heliotropium indicum L
}

\section{Plant Morphology}

$H$. indicum is an erect, thick fetid, annual or perennial herb with hirsute ascending branches, reaching between 20 and $60 \mathrm{~cm}$ in height [13]. The leaves are opposite or sub-opposite, alternate or sub-alternate and straight forward, sheet-shaped from ovate to elliptical, hairy, and sharp and $5-10 \mathrm{~cm}$ long. The margins of the leaves are undulate; the nerves present on both sides are serrulate or cordate and clearly visible under the leaves [21]. The petiole is about $1-7 \mathrm{~cm}$ long, while the flowers progress apically within the cymose; at maturity, nutlets are present at the base of the inflorescence. Generally, flowers are white or whitish violet in color, regular, sessile, axillary, and nearly $5 \mathrm{~mm}$ in diameter. Sepals are diffused with hairs outside, deep green in color, linear to lanceolate, uneven or unequal, and about 5-3 $\mathrm{mm}$ long. The fruits are dry and 2-4 lobed, with or without united nutlets, and 3-6 mm long. This species grows in sunny places preferring heights around $800 \mathrm{~m}$ [22]. Botanical descriptions of $H$. indicum are given in Table 1.

\section{Methodology}

The literature search was performed using the databases: Google Scholar, Scopus, SpringerLink, Web of Science, ScienceDirect, ResearchGate, PubMed, ChemSpider, Elsevier, BioMed Central, and USPTO, CIPO, INPI, Google Patents, and Espacenet. The scientific databases were chosen based on the topic covered (i.e., ethnobotany, ethnomedicinal uses, ethnopharmacology, pharmacology, phytochemistry, and therapeutic value) and geographical coverage (i.e., Asia and Africa). The common keyword "Heliotropium indicum" was used to search published materials, which was then paired with "traditional uses," "ethnopharmacology," "phytochemistry," "pharmacology," and "toxicity." Other literature sources included papers published in international journals; reports from international, regional, and national organizations; conference papers; and related books. Chemical structures were drawn using the software ChemSketch (Version 14.01).

\section{Traditional and Folk Values}

Ethnopharmacology is the study of medicinal plant use in specific cultural groups or the study of differences in response to drugs in different cultures [23]. About $90 \%$ of native people depend on the natural products of plant origin to treat several diseases [24]. With the knowledge 


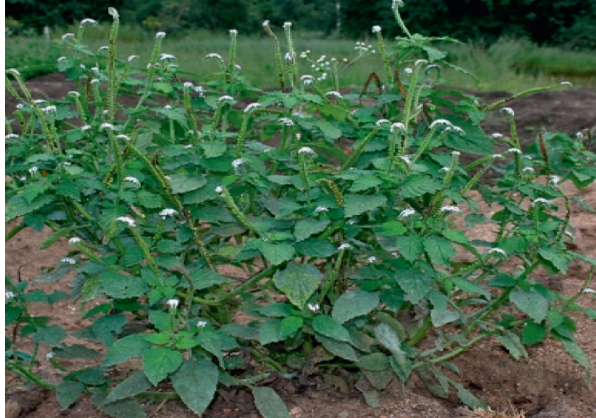

(a)

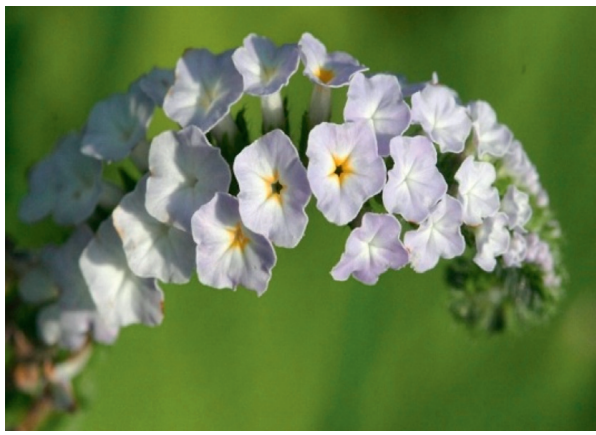

(c)

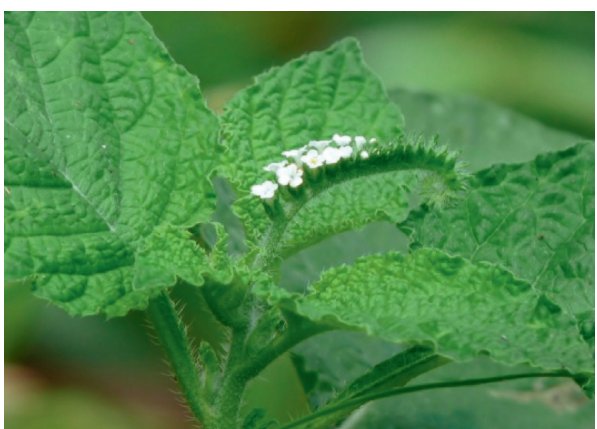

(b)

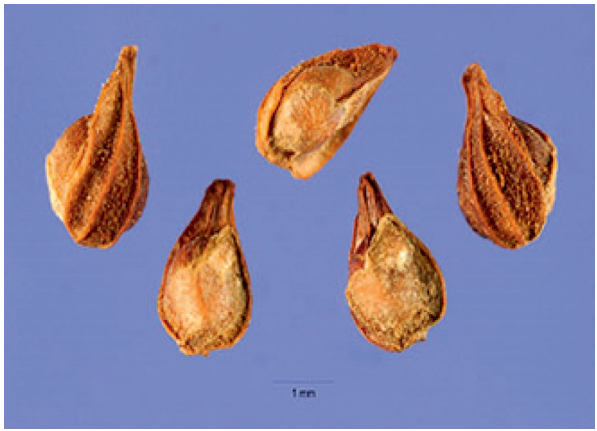

(d)

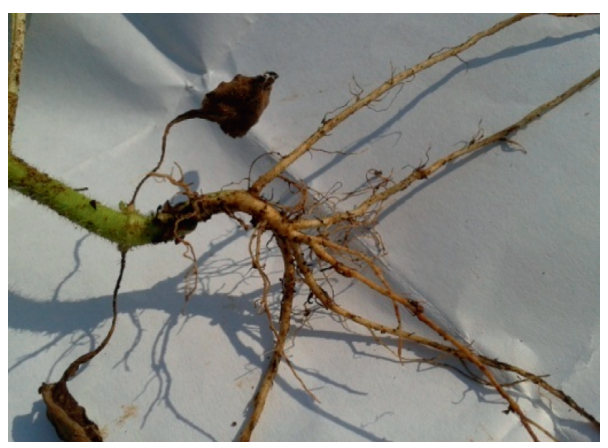

(e)

Figure 1: Different parts of Heliotropium indicum Linn:(a) whole plant, (b) leaves, (c) flowers, (d) seeds, and (e) roots.

of ethnopharmacology, the whole plant of $H$. indicum has been traditionally used in different folklore systems to cure several diseases in different countries over the world. In Bangladesh, the juice or decoction of leaves and roots of $H$. indicum is traditionally used in chicken pox, allergy, blood purification, swelling of the knees, joint pain, and severe itchy legs and also be used as an antidote to poisoning [12,25-27]. In India, different parts of the herb, mainly leaves as a paste or beverage, are used on wounds, skin infections, ophthalmia, snakebite, and scorpion sting $[28,29]$. The decoction of both root and leaf is used to handle whooping cough in children in eastern Nicaragua [13].

The infusion of flowers at low doses is applied to regulate the menstrual cycle, while large doses for abortion by introducing into the vaginal cavity. In Jamaica, the flower infusion is used by females to treat menorrhagia, while in Senegal and the Philippines, it is used to treat kidney stone
$[9,10]$. In the Philippines, the decoction of dried roots is drunk to encourage menses, while the seeds are used to heal wounds and treat cholera and malaria [30]. In African countries, it is reported that this plant is useful in treating malaria, dermatitis, abdominal pain, renal failure, and urinary infections $[9,31,32]$. In Thailand, the dried and powdered inflorescence $(1 \mathrm{gm})$ mixed with milk or water is used for three days beginning with the fourth day of menses to yield permanent sterilization in females [33]. The whole plant is used to treat ringworm infection and counteract putrefaction in Malaysia, while the decoction of the whole plant is applied to treat gonorrhea in Burma [30]. The leaf juice is used to treat the stings and boils of scorpions and insect bites. On the other hand, the boiled juice with castor oil is used to treat mad dog bite infections [34]. Moreover, $H$. indicum is also used to treat rheumatism [35], ulcer, venereal disease, fever, sore throat, and sores in the rectum [36]. Traditional uses of $H$. indicum in different countries are summarized in Table 2. 
TABLE 1: Botanical morphology of Heliotropium indicum L.

\begin{tabular}{|c|c|c|}
\hline Habitat & The disturbed a & $\begin{array}{l}\text { are garden or lawns, roadsides, anthropogenic habitats, and waste places. It is mostly found at a 1,000 m } \\
\text { altitude. }\end{array}$ \\
\hline \multirow[t]{2}{*}{ Foliage } & Leaves & $\begin{array}{l}4-10 \mathrm{~cm} \text { long and } 2-5 \mathrm{~cm} \text { wide, opposite, or sub-opposite, alternate or sub-alternate, ovate to obovate, } \\
\text { and acute, with a wavy or undulate, serrulate, or cordate leaf margin, nerves on either side or veins. The } \\
\text { leaf surface is covered with short hairs, which may be quite stiff. }\end{array}$ \\
\hline & Petiole & $1-7 \mathrm{~cm}$ long with a sub-truncate base or ovate \\
\hline \multirow{7}{*}{ Flowers } & 4-5 mm wide, & $\begin{array}{l}\text { ular, sessile, axillary, and slightly purple or white or whitish violet with a small yellow center and having a } \\
\text { narrow tube with lobes formed a plate shape }\end{array}$ \\
\hline & Inflorescence & $\begin{array}{c}\text { String or twisted of beads with a prominent curl at the apex. Flowers develop apically within the cymose } \\
\text { inflorescence. }\end{array}$ \\
\hline & Sepals & $\begin{array}{c}5 \text { in number, } 3 \mathrm{~mm} \text { long, diffused with hairs outside, deep green in color, linear to lanceolate, and uneven } \\
\text { or unequal }\end{array}$ \\
\hline & $\begin{array}{l}\text { Calyx lobes } \\
\text { ciliate }\end{array}$ & $3 \mathrm{~mm}$ long \\
\hline & Stamens & 5 in number and borne in a corolla tube, terminal, and corolla tube $4-6 \mathrm{~mm}$ long \\
\hline & Petals & Rounded \\
\hline & Ovary & 4 lobed \\
\hline Fruits & \multicolumn{2}{|c|}{$\begin{array}{l}\text { Fruits, also known as nutlets, are dry, indehiscent } 2-4 \text { lobed, } 3-6 \mathrm{~mm} \text { long, with or without united nutlets, ovate, and ribbed } \\
\text { separated into two nutlets. Each nutlet is two-celled and beaked. }\end{array}$} \\
\hline $\begin{array}{l}\text { Stem and } \\
\text { roots }\end{array}$ & \multicolumn{2}{|c|}{$\begin{array}{l}\text { Wide distributed, branched or unbranched, and hirsute with hairs in the stem. The root system is a long taproot and highly } \\
\text { branched. }\end{array}$} \\
\hline Genetics & \multicolumn{2}{|r|}{$2 n=22,24$} \\
\hline
\end{tabular}

\section{Phytochemical Constituents}

Based on the history of traditional and folk medicinal uses of $H$. indicum, many researchers have been investigating its phytochemical and pharmacological properties to identify the compounds responsible for its wide use as herbal medicines. The plant contains many important phytocomponents, including alkaloids (e.g., acetyl indicine, cynoglossine, echinitine, heleurine, heliotrine, helindicine, europine $N$-oxide, heleurine $\mathrm{N}$-oxide, heliotridine $\mathrm{N}$-oxide, heliotrine $\mathrm{N}$-oxide, indicine, indicinine, indicine $\mathrm{N}$-oxide, lasiocarpine, lycopsamine, trachelanthamidine, retronecine, and supinine), triterpenes (e.g., $\beta$-amyrin, lupeol, rapone, and rapanone), sterols (e.g., $\beta$-sitosterol, estradiol, chalinasterol, campesterol, hexacosane-1-ol, and stigmasterol), amines (e.g., putrescine, spermidine, and spermine), and volatile oils (e.g., 1-dodecanol, $\beta$-linalool, and phytol) $[30,53,62,65,67-72]$. Two new alkaloids, namely, heliotrine and indicine $N$-oxide, along with other alkaloids, including heleurine, supinine, echinitine, heliotrine, lasiocarpine $N$-oxide, acetyl indicine, indicinine, and retronecine, have been isolated from the aerial parts of $H$. indicum $[68,71,73,74]$. Europine $N$-oxide, cynoglossine, heliotrine $\mathrm{N}$-oxide, heleurine $\mathrm{N}$-oxide, and heliotridine $\mathrm{N}$ oxide were isolated from the seeds of this plant. Another new pyrrolizidine alkaloid, helindicine, has also been isolated from the roots of $H$. indicum [75]. The reported compounds are presented in Table 3, and the main representative compounds are shown in Figure 2.

\section{Pharmacological Activities}

Various solvent extracts (e.g., aqueous, chloroform, ethanolic, methanolic, and petroleum ether) of the whole plant of H. indicum as well as its various parts (e.g., root, stem, leaf, etc.) have been investigated to validate the folk value, and the results showed diverse biological effects on experimental animals, which are described in the present section. Pharmacological activities of different parts of $H$. indicum have been shown in Table 4.

7.1. Antioxidant Activity. The methanolic extract of various parts of the plant, such as leaf, stem, and roots, was used to measure the total phenolic compounds and flavonoids contents as well as to determine DPPH free radical scavenging activities. The inflorescence extracts presented a higher concentration of total phenolics and flavonoids with a $21.70 \mathrm{mg}$ gallic acid equivalent per gram (GAE/g) and $4.90 \mathrm{mg}$ quercetin equivalent per gram (QE/g), followed by leaves, stems, and roots. The percentage of free radical scavenging activity of the methanolic extracts of inflorescence, leaves, stems, and roots followed the same response pattern, with the maximum values for inflorescence $(77.78 \%)$ followed by leaves $(55.25 \%)$, stems (47.49\%), and roots $(<20 \%)$ with respect to the standard gallic acid and ascorbic acid [80]. In another study by the same authors, the potential antioxidant activity of methanolic extracts of callus of $\mathrm{H}$. indicum cultured for 30days at different temperatures $\left(20,25,30\right.$, and $\left.32^{\circ} \mathrm{C}\right)$ reported the highest $\mathrm{DPPH}$ scavenging activity $\left(\mathrm{IC}_{50}=53.17 \pm 1.43 \mu \mathrm{g} / \mathrm{mL}\right)$ at $30^{\circ} \mathrm{C}$ respect to the other temperatures [81]. In addition, another study reported that the ethanolic extract of $H$. indicum exerted more antioxidant capacity $\left(\mathrm{EC}_{50}: 28.91 \pm 4.26 \mu \mathrm{g} / \mathrm{mL}\right)$ than the water extract $\left(\mathrm{EC}_{50}:>100 \mu \mathrm{g} / \mathrm{mL}\right)[14]$.

7.2. Analgesic Activity. The analgesic effect of the ethanolic and aqueous extracts of the aerial parts of $H$. indicum $(30-300 \mathrm{mg} / \mathrm{kg})$ in a mouse model of formalin-induced pain was compared with the standard drugs, diclofenac sodium $(1-10 \mathrm{mg} / \mathrm{kg})$, and morphine $(1-10 \mathrm{mg} / \mathrm{kg})$. The neurogenic and inflammatory phases of the formalin-induced 
Table 2: Traditional uses of $H$. indicum $\mathrm{L}$.

\begin{tabular}{|c|c|c|c|c|c|}
\hline Country & Local names & $\begin{array}{l}\text { Traditional use as or } \\
\text { to treat }\end{array}$ & Part(s) used & Mode of administration & Reference(s) \\
\hline \multirow{5}{*}{ Bangladesh } & \multirow{5}{*}{ Hatisur } & $\begin{array}{l}\text { Antidote to } \\
\text { poisoning }\end{array}$ & $\begin{array}{l}\text { Leaves and } \\
\text { stem }\end{array}$ & $\begin{array}{l}\text { Decoction of leaves and stems is } \\
\text { administered orally. }\end{array}$ & {$[12]$} \\
\hline & & $\begin{array}{l}\text { Swelling of knees, } \\
\text { joint pain, and } \\
\text { severe itching in leg }\end{array}$ & Root & $\begin{array}{l}\text { Decoction or maceration of the } \\
\text { root is used through vocal order } \\
\text { (VO). }\end{array}$ & {$[25]$} \\
\hline & & Chicken pox & Leaves & Juice of roots is taken orally. & {$[26]$} \\
\hline & & Allergy & Leaves & Juice of the leaf is taken orally. & \\
\hline & & $\begin{array}{l}\text { Blood purification } \\
\text { and infections }\end{array}$ & Root & $\begin{array}{c}\text { Juice of roots is used both orally } \\
\text { and topically. }\end{array}$ & {$[27]$} \\
\hline Brazil & $\begin{array}{l}\text { Aguará-ciunhá-ac,ú and jacuá- } \\
\text { acanga }\end{array}$ & $\begin{array}{l}\text { Skin ulcers and } \\
\text { burns }\end{array}$ & Leaves & Unknown & {$[19,37]$} \\
\hline \multirow[t]{6}{*}{ Benin } & Koklosoudèn & Dystocia & Leaves & $\begin{array}{l}\text { Trituration with water and drops } \\
\text { in eyes }\end{array}$ & {$[38]$} \\
\hline & & Femal & Leaves & $\begin{array}{c}\text { Leaf extract is filtered then applied } \\
\text { through VO. }\end{array}$ & \\
\hline & & Leucorrhoea & Whole plant & $\begin{array}{c}\text { The diluted juice is administered } \\
\text { through VO. }\end{array}$ & \\
\hline & & Splenomegalia & Leaves & Unknown & \\
\hline & & Psychosis & $\begin{array}{l}\text { Leaves and } \\
\text { root }\end{array}$ & Unknown & \\
\hline & Koclossoudinkpatcha (Fon) & $\begin{array}{l}\text { Internal infection } \\
\text { and hypertension }\end{array}$ & $\begin{array}{l}\text { Stem and } \\
\text { leaves }\end{array}$ & $\begin{array}{l}\text { Decoction of stems with leaves is } \\
\text { applied through VO. }\end{array}$ & [39] \\
\hline Congo & Not registered & $\begin{array}{l}\text { Stomach, fever, and } \\
\text { eye lotion }\end{array}$ & Leaves & $\begin{array}{c}\text { Decoction of fresh leaves with } \\
\text { water that is taken } 1 \text { glass/day for } \\
1 \text { week. }\end{array}$ & {$[40]$} \\
\hline Colombia & Rabo de alacrán and verbena & Internal parasites & Leaves & Decoction of fresh leaves & {$[41]$} \\
\hline Guinea & Nasinko and hogghonhwan & $\begin{array}{l}\text { Diarrhea and } \\
\text { febrifuge }\end{array}$ & Whole plant & Decoction of the whole plant & {$[42]$} \\
\hline & & Antiseptic & Leaves & $\begin{array}{l}\text { The decoction of leaves is allowed } \\
\text { to administer through vocal order. }\end{array}$ & {$[43]$} \\
\hline Ghana & Komfemtikoro & $\begin{array}{l}\text { Paludism and eye } \\
\text { infections }\end{array}$ & Leaves & $\begin{array}{c}\text { Decoction of leaves is used for } \\
7 \text { days. }\end{array}$ & {$[44]$} \\
\hline Conakry & Not registered & Fever & Whole plant & Decoction of the whole plant & [9] \\
\hline Gabon & $\begin{array}{c}\text { (mo-)nyaka (w-)a mbumba (Eviya } \\
\text { language) }\end{array}$ & Gingivitis & Leaves & $\begin{array}{c}\text { Ground leaves of } H \text {. indicum for } \\
\text { local application }\end{array}$ & {$[45]$} \\
\hline \multirow[t]{3}{*}{ India } & Nakkipoo & $\begin{array}{l}\text { Snakebite and } \\
\text { scorpion sting }\end{array}$ & Leaves & $\begin{array}{l}\text { The leaf juice is used by mixing } \\
\text { with hot water. }\end{array}$ & {$[29]$} \\
\hline & Indian heliotrope and hatisundha & $\begin{array}{l}\text { Wounds and skin } \\
\text { infections }\end{array}$ & Whole plant & $\begin{array}{c}\text { Paste of the whole plant is applied } \\
\text { topically. }\end{array}$ & {$[28]$} \\
\hline & & Ophthalmia & Root & Juice of the root is taken orally. & {$[46]$} \\
\hline Ivory Coast & $\begin{array}{l}\text { Klaouri (Gouro), kotokorokombo } \\
\text { (Baoule), nansifo, nosiko } \\
\text { (Malinke), tapentiti, and taperodia } \\
\text { (Shien) }\end{array}$ & Colds and sinusitis & Leaves & Powder of dry leaves & [47] \\
\hline Indonesia & $\begin{array}{l}\text { Bandotanlombok, djingirajam, } \\
\text { gadjahan, tlale, and tusokkonde }\end{array}$ & $\begin{array}{l}\text { Herpes and } \\
\text { rheumatism }\end{array}$ & Leaves & $\begin{array}{l}\text { Decoction of leaf is used in thrush } \\
\text { and poultices. }\end{array}$ & [9] \\
\hline \multirow[t]{5}{*}{ Jamaica } & Turnsoles & Menorrhagia & Flower & $\begin{array}{c}\text { Infusion of the flower is taken } \\
\text { orally. }\end{array}$ & {$[48]$} \\
\hline & & $\begin{array}{l}\text { Fever, ulcers, } \\
\text { venereal diseases, } \\
\text { and sore throat }\end{array}$ & Whole plant & $\begin{array}{l}\text { Decoction of the whole plant is } \\
\text { taken orally. }\end{array}$ & \\
\hline & & Induced abortion & Whole plant & $\begin{array}{l}\text { Decoction of the whole plant is } \\
\text { applied to the vaginal cavity. }\end{array}$ & \\
\hline & & Rectal sores & Whole plant & $\begin{array}{l}\text { Decoction of the whole plant is } \\
\text { administered rectally. }\end{array}$ & \\
\hline & & $\begin{array}{l}\text { Cleansing and } \\
\text { dressing of wounds } \\
\text { and ulcers }\end{array}$ & Whole plant & Paste of fresh plant & \\
\hline Mauritius & $\begin{array}{l}\text { Herbepapillon (Creole) and } \\
\text { taylkoudougou (Tamoul) }\end{array}$ & Renal colic & Leaves & Infusion of 4 or 5 green leaves & {$[32,49]$} \\
\hline
\end{tabular}


TABLE 2: Continued.

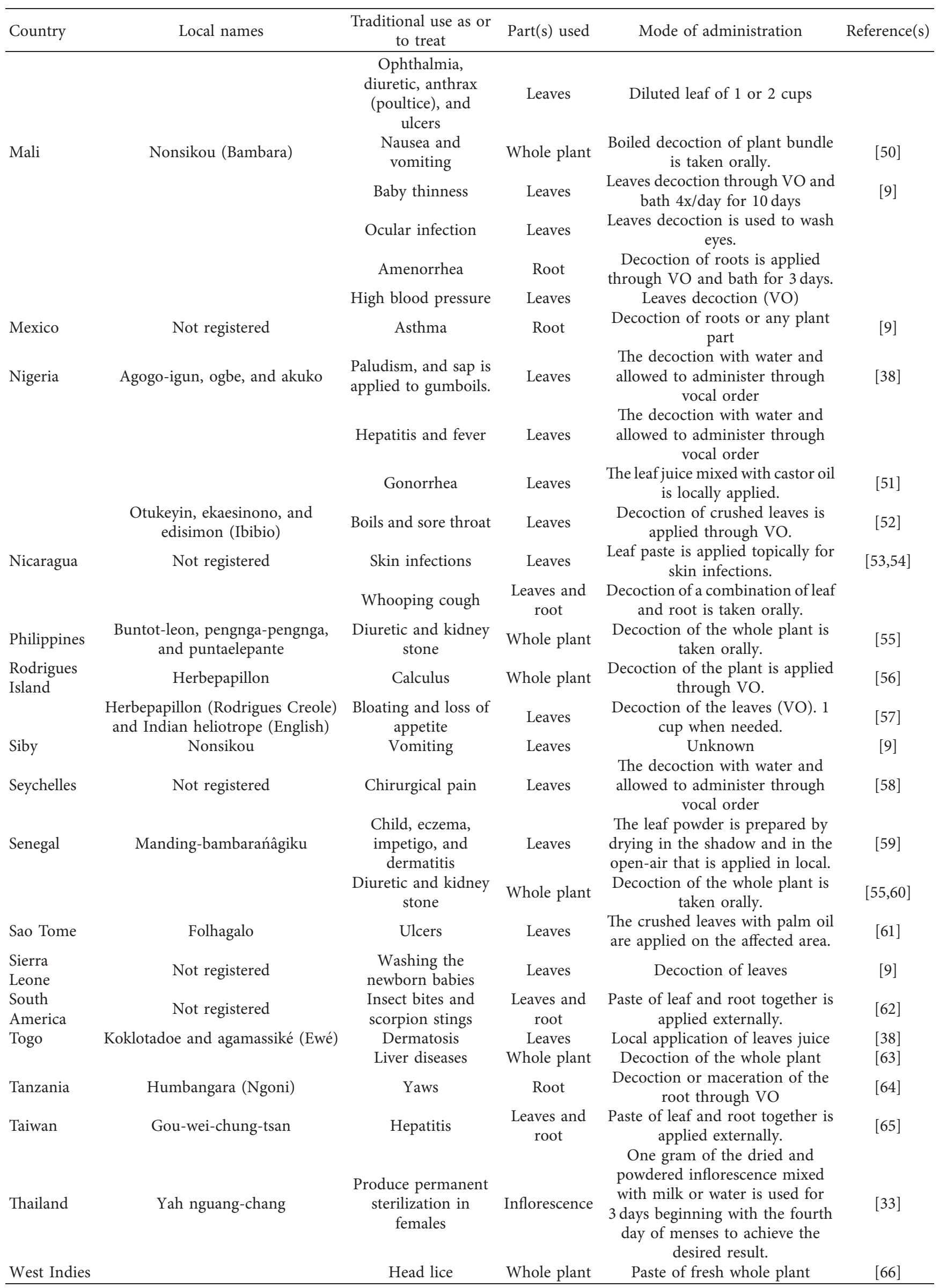


TABle 3: Chemical compounds isolated from H. indicum L.

\begin{tabular}{|c|c|c|}
\hline Phytochemicals & Part(s) & Reference(s) \\
\hline \multicolumn{3}{|l|}{ Alkaloids } \\
\hline Cynoglossine & Seed & {$[67]$} \\
\hline Echinatine & Aerial & [53] \\
\hline Heleurine & Aerial & {$[62]$} \\
\hline Heliotrine & Aerial & {$[62]$} \\
\hline Heliotridine & Aerial & {$[62]$} \\
\hline Helindicine & Root & {$[75]$} \\
\hline Europine $N$-oxide & Seed & {$[67]$} \\
\hline Heleurine $N$-oxide & Seed & [67] \\
\hline Heliotridine $N$-oxide & Seed & {$[67]$} \\
\hline Heliotrine $N$-oxide & Seed & [67] \\
\hline Indicine & Aerial & [53] \\
\hline Indicine $N$-oxide & Aerial & {$[71]$} \\
\hline Lasiocarpine & Aerial & {$[65]$} \\
\hline Lycopsamine & Root & {$[75]$} \\
\hline Trachelanthamidine & Leaves & {$[76]$} \\
\hline Retronecine & Leaves and aerial & {$[73,76]$} \\
\hline Supinine & Aerial & {$[53]$} \\
\hline \multicolumn{3}{|l|}{ Triterpenes } \\
\hline$\beta$-Amyrin & Whole plant & {$[77]$} \\
\hline Lupeol & Aerial and whole plant & {$[71,77]$} \\
\hline Rapanone & Whole plant & {$[77]$} \\
\hline \multicolumn{3}{|l|}{ Sterols } \\
\hline$\beta$-Sitosterol & Whole plant & {$[77]$} \\
\hline Estradiol & Root & [78] \\
\hline Chalinasterol & Whole plant & {$[77]$} \\
\hline Campesterol & Whole plant & {$[77]$} \\
\hline Hexacosane-1-ol & Whole plant & {$[77]$} \\
\hline Stigmasterol & Whole plant & [77] \\
\hline \multicolumn{3}{|l|}{ Amines } \\
\hline Putrescine & Leaves & {$[76]$} \\
\hline Spermidine & Leaves & {$[76]$} \\
\hline Spermine & Leaves & {$[76]$} \\
\hline \multicolumn{3}{|l|}{ Volatile oils } \\
\hline 1-Dodecanol & Whole plant & [79] \\
\hline$\beta$-Linalool & Whole plant & [79] \\
\hline Phytol & Whole plant & [79] \\
\hline
\end{tabular}

nociception were inhibited dose-dependently by both the aqueous and ethanolic extracts, suggesting a potential analgesic application $[82,101]$. However, toxicity studies reported that 14-day oral administration of $1-2 \mathrm{~g} / \mathrm{kg}$ of $H$. indicum aqueous extracts induced pathologic effects on the heart, kidney, liver, and lungs; therefore, prolonged and continuous use is not recommended.

7.3. Antinociceptive Activity. The methanol root extract of $H$. indicum exhibited 34.76 and $64.67 \%$ writhing inhibition in Swiss albino mice at 250 and $500 \mathrm{mg} / \mathrm{kg}$ of body weight (po), respectively, whereas the standard drug diclofenac sodium showed $66.67 \%$ writhing inhibition at the clinically established dose of $25 \mathrm{mg} / \mathrm{kg}$ for mice [7]. Another study suggested that the chloroform extract of leaves of $H$. indicum showed maximum antinociception effect $(82.79 \%)$ at $150 \mathrm{mg} / \mathrm{kg}$ of body weight in the hotplate test in male Swiss albino mice that was compared with the standard drug, pentazocine [83].
7.4. Antinflammatory Activity. The antiinflammatory activity of methanolic root extracts of $H$. indicum $(100 \mathrm{mg} / \mathrm{kg})$ was assayed against carrageenin-induced acute paw edema and cotton pellet granuloma sub-acute inflammation models, and the standard drugs acetylsalicylic acid for the acute assay and phenylbutazone for the sub-acute assay were used as positive controls [18]. The extract evidenced a significant antiinflammatory activity with a $49.05 \%$ reduction in paw edema and $55.09 \%$ reduction in granuloma formation. These results were similar to those obtained by positive controls using the same concentration of $100 \mathrm{mg} / \mathrm{kg}$. In another study, the ethanolic and petroleum ether extracts of $H$. indicum $(25 \mathrm{mg} / \mathrm{kg})$ were investigated in an egg-whiteinduced acute paw edema rat model [84]. Both extracts evidenced notable antiinflammatory effects, reporting similar values to the standard reference ketorolac trimethamine $(10 \mathrm{mg} / \mathrm{kg})$. The chloroform leaf extract of $H$. indicum extract (150 mg/kg of body weight) also showed a significant antiinflammatory effect $(80.0 \%)$ on carrageenan-induced paw edema in albino Wistar rats [83]. An aqueous whole plant extract of $H$. indicum (30-300 mg/kg, p.o.) showed an antiinflammatory effect on the lipopolysaccharide-induced uveitic rabbits. The extract and prednisolone (positive control) expressively reduced both the clinical scores of inflammation and inflammatory cell infiltration compared with the negative control group [85]. A pharmaceutical oral product obtained from $H$. indicum is used against acute and chronic inflammation, particularly against inflammatory diseases of the intestines [102].

7.5. Antimicrobial Activity. The alcoholic extract with a percentage yield of $7.2 \% \mathrm{w} / \mathrm{w}$ of the whole plant showed a concentration-dependent $(1-100 \mathrm{mg} / \mathrm{mL})$ antibacterial activity against Bacillus subtilis, Bacillus pumilus, Staphylococcus aureus, Micrococcus glutamicus, Pseudomonas aeruginosa, Proteus vulgaris, Serratia marcescens, and Escherichia coli. The alcoholic extract also showed antifungal activity against Aspergillus niger, Aspergillus wentii, Rhizopus oryzae, Saccharomyces cerevisiae, and Candida albicans $[8,86]$. However, as high extract concentrations are required to observe inhibitory effects, activity-directed assays are necessary to isolate and characterize the active metabolite responsible for the observed activity. The petroleum ether, chloroform, aqueous, and methanolic extracts of $\mathrm{H}$. indicum leaves showed antimicrobial activity against both Grampositive and Gram-negative bacteria, such as B. subtilis, S. aureus, $P$. aeruginosa, and E. coli [6,37]. In a wound infection model with $S$. aureus and $P$. aeruginosa, the methanolic and aqueous extracts of leaves mixed with a simple ointment $(10 \% \mathrm{w} / \mathrm{w})$ presented the most promising activity favoring the healing similarly to the reference standard nitrofurazone [37]. In another study, the antimicrobial screening of petroleum and methanolic extracts of the aerial parts of the plant evidenced significant zones of inhibition against the three previously mentioned microorganisms [6].

The aqueous ethanol and chloroform extract of the whole plant of $H$. indicum showed antibacterial and 


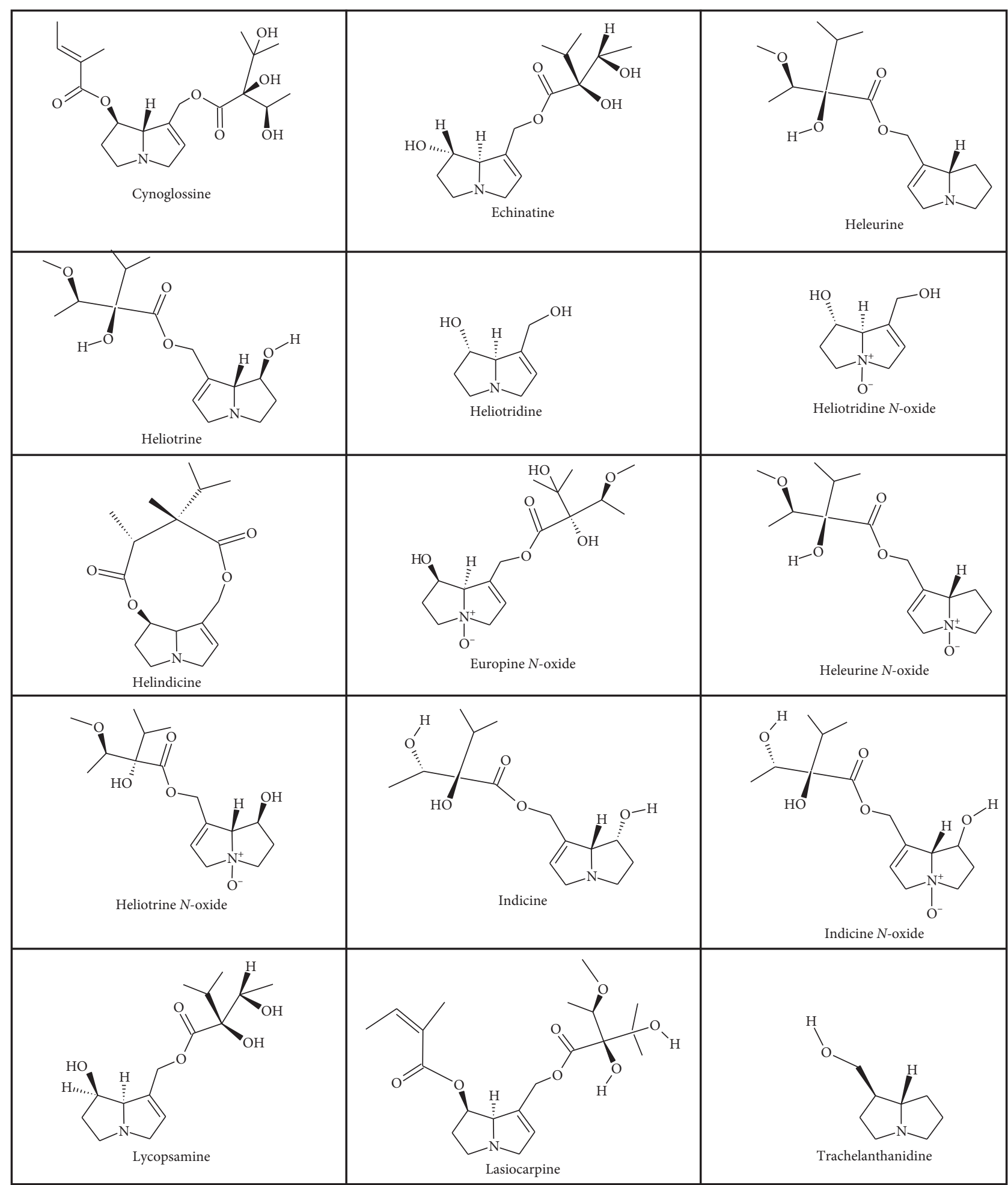

(a)

FIgURE 2: Continued. 


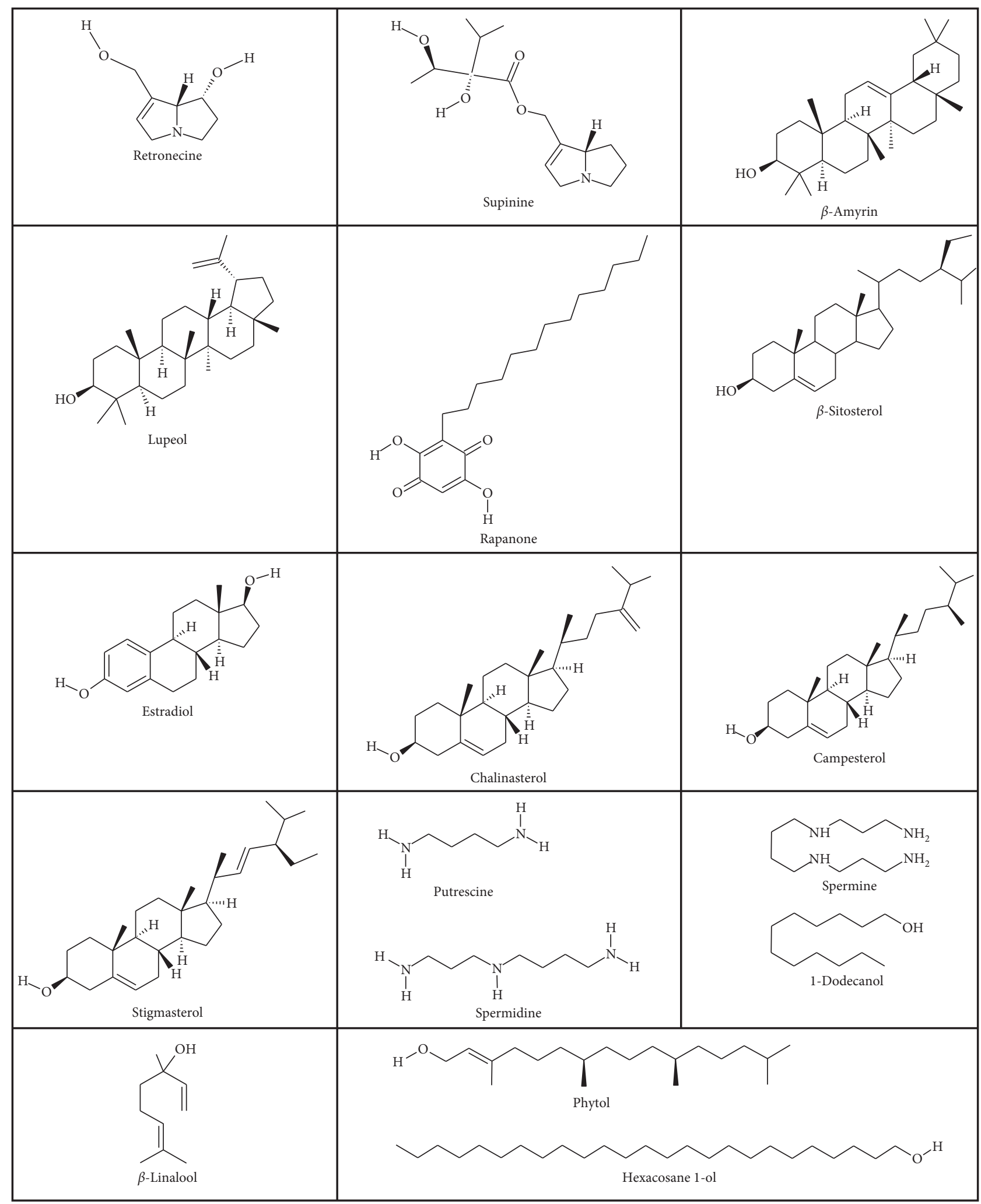

(b)

FIgURE 2: Some important isolated compounds from $H$. indicum L. 
Table 4: Pharmacological activities of different parts of $H$. indicum L.

\begin{tabular}{|c|c|c|c|c|}
\hline Activity & Extract & Method & Results & References \\
\hline \multirow[t]{3}{*}{ Antioxidant activity } & $\begin{array}{l}\text { Methanolic extract of leaf, } \\
\text { stem, and root }\end{array}$ & $\begin{array}{c}\text { DPPH free radical scavenging } \\
\text { assay }\end{array}$ & $\begin{array}{l}\text { Leaf extract yields greater free } \\
\text { radical scavenging activity than } \\
\text { the stem and roots. }\end{array}$ & {$[80]$} \\
\hline & Aqueous leaf extract & & $\begin{array}{l}\text { Show high free radical scavenging } \\
\text { activity compared with Centella } \\
\text { asiatica, Coccinia grandis, and } \\
\text { Euphorbia hirta. }\end{array}$ & {$[81]$} \\
\hline & $\begin{array}{c}\text { Ethanol and water extracts } \\
\text { of the whole plant }\end{array}$ & & $\begin{array}{l}\text { Ethanolic extract showed high } \\
\text { antioxidant activity. }\end{array}$ & {$[14]$} \\
\hline Analgesic activity & $\begin{array}{l}\text { Aqueous and ethanol } \\
\text { extracts of the whole plant }\end{array}$ & $\begin{array}{l}\text { In vivo: Formalin-induced } \\
\text { nociception in mice }\end{array}$ & $\begin{array}{l}\text { Both extracts have analgesic } \\
\text { activity. }\end{array}$ & {$[82]$} \\
\hline \multirow[t]{2}{*}{$\begin{array}{l}\text { Antinociceptive } \\
\text { activity }\end{array}$} & $\begin{array}{l}\text { Methanolic extract of the } \\
\text { roots }\end{array}$ & $\begin{array}{l}\text { Acetic-acid-induced writhing in } \\
\text { mice }\end{array}$ & $\begin{array}{l}\text { Extract produced writhing } \\
\text { inhibition in the test animals. }\end{array}$ & {$[7]$} \\
\hline & $\begin{array}{c}\text { Chloroform extract of } \\
\text { leaves }\end{array}$ & $\begin{array}{l}\text { Hot-plate model in male Swiss } \\
\text { albino mice }\end{array}$ & $\begin{array}{l}\text { Extract showed writhing } \\
\text { inhibition in mice. }\end{array}$ & {$[83]$} \\
\hline \multirow[t]{3}{*}{$\begin{array}{l}\text { Antiinflammatory } \\
\text { activity }\end{array}$} & $\begin{array}{l}\text { Methanol extracts of leaf, } \\
\text { stem, and root }\end{array}$ & $\begin{array}{l}\text { Egg-albumin- and carrageenin- } \\
\text { induced acute paw edema models } \\
\text { and cotton pellet granuloma sub- } \\
\text { acute inflammation model }\end{array}$ & $\begin{array}{l}\text { Extract of roots produced a } \\
\text { significant antiinflammatory } \\
\text { effect in acetic-acid-induced } \\
\text { writhing in mice. }\end{array}$ & {$[18,84]$} \\
\hline & $\begin{array}{l}\text { Chloroform extract of } \\
\text { leaves }\end{array}$ & $\begin{array}{c}\text { Carrageenan-induced raw paw } \\
\text { edema }\end{array}$ & $\begin{array}{l}\text { The extract showed maximum } \\
\text { inhibition on carrageenan- } \\
\text { induced rat paw edema. }\end{array}$ & {$[83]$} \\
\hline & $\begin{array}{l}\text { Aqueous whole plant } \\
\text { extract }\end{array}$ & $\begin{array}{c}\text { Lipopolysaccharide (LPS) induced } \\
\text { uveitis rabbits }\end{array}$ & $\begin{array}{l}\text { The extract reduced both the } \\
\text { clinical scores of inflammation } \\
\text { and inflammatory cells } \\
\text { infiltration. }\end{array}$ & {$[85]$} \\
\hline \multirow[t]{5}{*}{ Antimicrobial activity } & $\begin{array}{l}\text { Alcoholic extract of the } \\
\text { whole plant }\end{array}$ & Agar cup plate diffusion method & $\begin{array}{l}\text { The alcoholic extract was found to } \\
\text { possess dose-dependent } \\
\text { antimicrobial activity against } \\
\text { bacteria, fungi, and yeasts, }\end{array}$ & {$[8,86]$} \\
\hline & $\begin{array}{l}\text { Petroleum ether, } \\
\text { chloroform, aqueous, and } \\
\text { methanolic extracts of } \\
\text { leaves }\end{array}$ & & $\begin{array}{c}\text { All extracts show effective } \\
\text { antimicrobial activity against both } \\
\text { Gram-positive and Gram- } \\
\text { negative bacteria }\end{array}$ & {$[6,37]$} \\
\hline & $\begin{array}{l}\text { Aqueous, ethanol, and } \\
\text { chloroform extracts of the } \\
\text { whole plant }\end{array}$ & & $\begin{array}{c}\text { Had significant zones of } \\
\text { inhibition against bacteria and } \\
\text { fungi. }\end{array}$ & [87] \\
\hline & $\begin{array}{c}\text { Methanol whole plant } \\
\text { extracts }\end{array}$ & & $\begin{array}{l}\text { Exhibited both antibacterial and } \\
\text { antifungal activity. }\end{array}$ & {$[88]$} \\
\hline & Methanol leaves extract & & Had an antibacterial activity. & {$[8]$} \\
\hline $\begin{array}{l}\text { Antituberculosis } \\
\text { activity }\end{array}$ & $\begin{array}{l}\text { Volatile oil of } H \text {. indicum } \\
\text { from aerial parts }\end{array}$ & $\begin{array}{l}\text { Alamar blue assay system with an } \\
\text { MIC }\end{array}$ & $\begin{array}{c}\text { Had profound antituberculosis } \\
\text { activity against Mycobacterium } \\
\text { tuberculosis H37Ra. }\end{array}$ & [79] \\
\hline $\begin{array}{l}\text { Antihyperglycemic } \\
\text { activity }\end{array}$ & $\begin{array}{l}\text { Whole plant methanol } \\
\text { extracts }\end{array}$ & $\begin{array}{l}\text { Tested on the fasting blood glucose } \\
\text { levels of streptozotocin-induced } \\
\text { (STZ-induced) diabetic rats }\end{array}$ & $\begin{array}{c}\text { Showed a conspicuous reduction } \\
\text { in blood glucose levels and } \\
\text { normalization of blood glucose } \\
\text { levels. }\end{array}$ & [89] \\
\hline \multirow[t]{2}{*}{ Anticataract activity } & Ethanolic leaf extract & Galactose-induced cataract in rats & $\begin{array}{l}\text { Significantly increased the lens } \\
\text { glutathione. }\end{array}$ & {$[20]$} \\
\hline & $\begin{array}{l}\text { Aqueous extract of the } \\
\text { whole plant }\end{array}$ & $\begin{array}{l}\text { Selenite-induced cataracts in } \\
\text { Sprague-Dawley rats }\end{array}$ & $\begin{array}{c}\text { Expressively inhibited the } \\
\text { development of selenite-induced } \\
\text { cataracts. }\end{array}$ & {$[90]$} \\
\hline $\begin{array}{l}\text { Antiplasmodial } \\
\text { properties }\end{array}$ & $\begin{array}{l}\text { Dichloromethane, } \\
\text { methanol, and total } \\
\text { aqueous extracts of the } \\
\text { whole plant }\end{array}$ & $\begin{array}{l}\text { Tested on chloroquine-sensitive } \\
\text { (3D7) and resistant (W2) strains of } \\
\text { Plasmodium falciparum }\end{array}$ & $\begin{array}{l}\text { Revealed no direct antiplasmodial } \\
\text { activity. }\end{array}$ & {$[91]$} \\
\hline Antifertility activity & $\begin{array}{l}\text { Petroleum ether extract of } \\
\text { the whole plant }\end{array}$ & In vivo test on rats & Exhibited profound activity. & {$[77]$} \\
\hline
\end{tabular}


TABLE 4: Continued.

\begin{tabular}{|c|c|c|c|c|}
\hline Activity & Extract & Method & Results & References \\
\hline & $\begin{array}{l}\text { Extract of the n-hexane and } \\
\text { benzene fractions of whole } \\
\text { plant }\end{array}$ & $\begin{array}{l}\text { Antiimplantation and } \\
\text { abortifacient models in rats }\end{array}$ & $\begin{array}{l}\text { Had substantial antifertility } \\
\text { activity. }\end{array}$ & {$[92]$} \\
\hline Anthelmintic activity & Methanolic extract of leaves & In vitro anthelmintic bioassay & $\begin{array}{l}\text { The extract showed significant } \\
\text { anthelmintic efficacy. }\end{array}$ & {$[93]$} \\
\hline \multirow[t]{2}{*}{ Antitumor activity } & $\begin{array}{l}\text { Methanolic extract of both } \\
\text { stem and leaf }\end{array}$ & MTT assay on HeLa cell lines & $\begin{array}{c}\text { Both extracts exhibited } \\
\text { antiproliferative activity where the } \\
\text { stem extract showed interesting } \\
\text { results. }\end{array}$ & {$[94]$} \\
\hline & $\begin{array}{c}\text { Ethanolic extract of the } \\
\text { whole plant }\end{array}$ & $\begin{array}{l}\text { MTT assay on SKBR3 human } \\
\text { breast adenocarcinoma cell line }\end{array}$ & $\begin{array}{l}\text { Showed momentous } \\
\text { antiproliferative activity. }\end{array}$ & {$[91]$} \\
\hline Antitussive property & Ethanolic extract of leaves & $\begin{array}{l}\text { The citric acid saturated chamber } \\
\text { in animals }\end{array}$ & $\begin{array}{c}\text { Extract syrup recorded the lowest } \\
\text { number of coughs. }\end{array}$ & {$[95]$} \\
\hline Antiglaucoma activity & $\begin{array}{l}\text { Aqueous whole plant } \\
\text { extract }\end{array}$ & Glaucoma of rabbits in vivo & $\begin{array}{l}\text { Significantly reduced intraocular } \\
\text { pressure in acute and chronic } \\
\text { glaucoma. }\end{array}$ & {$[90]$} \\
\hline \multirow[t]{3}{*}{$\begin{array}{l}\text { Wound-healing } \\
\text { activity }\end{array}$} & $\begin{array}{l}\text { Dried parts of ethanolic } \\
\text { extracts }\end{array}$ & $\begin{array}{c}\text { Excision and restored incision } \\
\text { wound model }\end{array}$ & Showed wound-healing capacity. & {$[19]$} \\
\hline & $\begin{array}{l}n \text {-Butanol fractions aerial } \\
\text { part (stem and leaves) }\end{array}$ & The scratch assay & $\begin{array}{l}\text { The isolated compound contains } \\
\text { profound wound-healing activity. }\end{array}$ & {$[96]$} \\
\hline & $\begin{array}{l}\text { The petroleum ether, } \\
\text { chloroform, methanol, and } \\
\text { aqueous extracts of leaves. }\end{array}$ & $\begin{array}{l}\text { Excision (normal and infected), } \\
\text { incision, and dead space wound } \\
\text { models in rats }\end{array}$ & $\begin{array}{c}\text { Methanol and aqueous extracts } \\
\text { attributed intense wound-healing } \\
\text { activity. }\end{array}$ & {$[37]$} \\
\hline $\begin{array}{l}\text { Histo-gastroprotective } \\
\text { activity }\end{array}$ & $\begin{array}{l}\text { Aqueous extract of the } \\
\text { dried leaves }\end{array}$ & $\begin{array}{c}\text { Indomethacin-induced gastric } \\
\text { ulcerated mucosa in rats }\end{array}$ & $\begin{array}{l}\text { Had effective histo- } \\
\text { gastroprotective activity. }\end{array}$ & {$[10]$} \\
\hline Diuretic activity & $\begin{array}{l}\text { Methanolic extract of the } \\
\text { dried roots }\end{array}$ & $\begin{array}{c}\text { Biuret, a urea derivative assayed by } \\
\text { the electrolyte loss ratio }\left(\mathrm{Na}^{+} / \mathrm{K}^{+}\right. \\
\text {excretion ratio }) \text { in mice }\end{array}$ & $\begin{array}{l}\text { The extract revealed a marked } \\
\text { diuretic effect. }\end{array}$ & {$[7]$} \\
\hline $\begin{array}{l}\text { Relaxant/receptor } \\
\text { property }\end{array}$ & Ethanol extract of the roots & $\begin{array}{l}\text { Guinea pig ileum and rabbit } \\
\text { duodenum in vitro }\end{array}$ & $\begin{array}{l}\text { Possess weak smooth muscle } \\
\text { relaxant activity. }\end{array}$ & {$[97]$} \\
\hline \multirow{3}{*}{$\begin{array}{l}\text { Clot lysis and } \\
\text { membrane-stabilizing } \\
\text { activities }\end{array}$} & $\begin{array}{l}\text { Dark-brown solid extract of } \\
\text { aerial parts }\end{array}$ & $\begin{array}{c}\text { Guinea pig ileum, rabbit jejunum, } \\
\text { rat uterus, and rat anococcygeus } \\
\text { preparations in vivo }\end{array}$ & $\begin{array}{l}\text { Showed profound receptor } \\
\text { property }\end{array}$ & {$[98]$} \\
\hline & $\begin{array}{c}\text { Ethanolic, petroleum ether, } \\
\text { carbon tetrachloride, and } \\
\text { chloroform extracts of } \\
\text { leaves }\end{array}$ & $\begin{array}{l}\text { Membrane-stabilizing and } \\
\text { thrombolytic activities in vitro }\end{array}$ & $\begin{array}{l}\text { Had potential clot lysis and } \\
\text { membrane-stabilizing activities. }\end{array}$ & [99] \\
\hline & $\begin{array}{l}\text { Methanol extract of the } \\
\text { whole plant }\end{array}$ & $\begin{array}{l}\text { In vitro thrombolytic model and } \\
\text { membrane-stabilizing activity } \\
\text { assay on human RBC subjected to } \\
\text { heat and hypotonic stress }\end{array}$ & $\begin{array}{l}\text { Protected the hemolysis of RBCs } \\
\text { induced by hypotonic solution } \\
\text { and heat stress. }\end{array}$ & {$[88]$} \\
\hline Antiallergic activity & $\begin{array}{l}\text { Aqueous whole plant } \\
\text { extract }\end{array}$ & $\begin{array}{c}\text { Ovalbumin-induced allergic } \\
\text { conjunctivitis on Dunkin-Hartley } \\
\text { guinea pigs }\end{array}$ & $\begin{array}{l}\text { Exhibited antiallergic effect } \\
\text { possibly by immunomodulation } \\
\text { or immunosuppression. }\end{array}$ & {$[90]$} \\
\hline Larvicidal activity & Ethanolic leaf extract & $\begin{array}{c}\text { Larvicidal bioassay on mosquito } \\
\text { larvae of Aedes aegypti }\end{array}$ & $\begin{array}{l}\text { The extract showed effective } \\
\text { mosquito larvicidal activity. }\end{array}$ & {$[100]$} \\
\hline Pesticidal activity & $\begin{array}{l}\text { Ethanol extract of aerial } \\
\text { parts }\end{array}$ & Brine shrimp lethality bioassay & $\begin{array}{l}\text { Possess potent activity against the } \\
\text { brine shrimp nauplii. }\end{array}$ & [7] \\
\hline
\end{tabular}

antifungal activities, where it produced significant zones of inhibition against $70 \%$ of the tested organisms, using amikacin (5 g/disc) as a positive control [87]. Among the different extracts, chloroform is the one that showed the best results, although the zone of inhibition was always lower than for amikacin (e.g., for S. aureus, the inhibition diameter was $19 \mathrm{~mm}$ for the control and $12 \mathrm{~mm}$ for chloroform extract). The methanol extract of the whole plant also showed activity against five Gram-positive and eight Gram-negative bacteria and three fungi, using the standard antibiotic, ciprofloxacin, as a positive control [88]. In addition, the carbon tetrachloride soluble materials obtained by the fractionation of the methanolic extract using a rotary evaporator revealed notable activity against a number of microbes with zones of inhibition ranging from 7 to $20 \mathrm{~mm}$, showing the highest inhibitory capacity for Bacillus cereus $(20.0 \mathrm{~mm})$ [88]. The methanol extract of $H$. indicum leaves $(6.25,12.5,25,50,100$, and $200 \mathrm{mg} / \mathrm{mL})$ showed activity against $S$. aureus, $P$. aeruginosa, Proteus mirabilis, and E. coli, where the diameters of the zones of inhibition were $6 \mathrm{~mm}$ 
[8]. However, the high concentration required to obtain inhibition, compared with the positive control (gentamycin, $10 \mathrm{mg} / \mathrm{ml}$ ), suggests a low antimicrobial capacity of the extract. The volatile oil isolated from the aerial parts of $H$. indicum with phytol (49.1\%), 1-dodecanol (6.4\%), and $\beta$-linalool $(3.0 \%)$ as main compounds showed antituberculosis activity against Mycobacterium tuberculosis H37Ra with an MIC value of $20.8 \mu \mathrm{g} / \mathrm{mL}$, using the drugs, isoniazid, and kanamycin, as positive controls [79].

7.6. Antihyperglycemic Effect. Administration of the whole plant methanol extract among the different solvent extracts of $H$. indicum $(250,500,750$, or $1,000 \mathrm{mg} / \mathrm{kg})$ on the fasting blood glucose levels of streptozotocin-induced (STZ-induced) diabetic rats showed a significant reduction (31.5\%) but less antihyperglycemic activity in comparison with the aqueous extract (47\%) and methanol active fraction (750 mg/kg of body weight) of the plant (60\%) [89].

7.7. Anticataract Effect. The ethanolic leaf extract of $H$. indicum ( $200 \mathrm{mg} / \mathrm{kg}$ of body weight) showed a significant anticataract activity in rats. The results showed that there was a significant increase in the lens glutathione, soluble protein, and water content in the groups of H. indicum and vitamin-E-treated animals than the galactose-containing control group [20]. Another study showed that the aqueous extracts of the whole plant (including aerial and root parts) significantly inhibited the development of selenite-induced cataracts in Sprague-Dawley rats [90].

7.8. Antiplasmodial Properties. In order to find out its scientific relevance to the traditional use in malaria, the extracts of $H$. indicum were undergone for the evaluation of antiplasmodial activity. However, $H$. indicum methanolic extracts had not shown clear antiplasmodial effects assayed in vitro against chloroquine-resistant (K1) and sensitive (FCR3) strains, and antiTrypanosoma effects were assayed in Trypanosoma brucei brucei GUT at 3.1 strain [91]. Its use in traditional medicine can be explained by its activity in reducing hyperthermia and colic, which are two symptoms of malaria [103].

7.9. Antifertility Activity. Antifertility and abortifacient activity of petroleum ether extract of $H$. indicum were significant in rats, which validated the ethnomedicinal use of this plant as an antifertility agent [77]. The n-hexane and benzene fractions of the ethanol extract of the whole plant also showed antifertility activity using antiimplantation and abortifacient models in rats [92].

7.10. Anthelmintic Effect. The anthelmintic effects of methanolic and aqueous leaf extracts of $H$. indicum $(25,50$, and $100 \mathrm{mg} / \mathrm{mL}$ ) were tested against the Indian adult earthworm, Pheretima posthuma. Mebendazole was used as a reference standard using the same concentrations as the extract. The time to paralysis and death progressively decreased in parallel with the increase in the concentrations of the methanolic extract, showing results similar to those of the standard drug mebendazole [93]. On the contrary, the effects of the aqueous extract were much smaller and not very effective against $P$. posthuma.

7.11. AnticancerEffect. The methanolic extract of $H$. indicum roots $(10,20,40,80$, and $160 \mu \mathrm{g} / \mathrm{mL})$ showed a potent cytotoxic effect on the brine shrimp nauplii [7]. The $\mathrm{LC}_{50}$ values were ranged from 2.57 to $31.44 \mu \mathrm{g} / \mathrm{mL}$. The crude methanol extract also showed cytotoxic effects on brine shrimp nauplii with the $\mathrm{LC}_{50}$ value of $2.57 \pm 0.22 \mu \mathrm{g} / \mathrm{mL}$ as compared with $0.45 \mu \mathrm{g} / \mathrm{mL}$ for positive control vincristine sulphate [88]. In another study, the anticancer effects of the methanolic extracts of stem and leaves were investigated against HeLa cell line [94]. Both methanolic extracts exhibited antiproliferative activity after $48 \mathrm{~h}$ of treatment, evidencing a relative death percentage of $64.5 \%$ for the methanolic extract of stem at $200 \mu \mathrm{g} / \mathrm{mL}$ and $49.7 \%$ for the leaf extract at the same concentration with respect to control cell supplemented only with the vehicle [94]. The ethanolic extract of the whole plant was also found to exert a significant antiproliferative effect on SKBR3 human breast adenocarcinoma cell line [91]. Indicine $N$-oxide, which is the principal pyrrolizidine alkaloid isolated from this plant has reached phase 1 clinical trial in advanced cancer patients with the risk of hepatotoxicity [104].

7.12. Antitussive Effect. The ethanolic leaf extract of $H$. indicum showed an antitussive effect on experimental animals. While statistically comparable with dextromethorphan, the results of the investigation showed that $50 \%$ and $100 \%$ ethanolic extract syrup reduced the coughing score by 4.67 and 2.0, respectively [95].

7.13. Antiglaucoma Activity. The aqueous whole plant extract of $H$. indicum (30-300 mg/kg of body weight) significantly reduced the intraocular pressure in acute and chronic glaucoma, preserved glutathione levels, and glutamate concentration in rabbits [90].

7.14. Wound Healing Capacity. The alcoholic extract of $H$. indicum showed wound-healing activity in animal models. In a rat model, topical application of $10 \% \mathrm{w} / \mathrm{v}$ $H$. indicum showed a complete wound-healing capacity on the $14^{\text {th }}$ day [19]. Two alkaloids, pestalamide B and glycinamide, $N$-(1-oxooctadecyl) glycyl-lalanylglycyl-L-histidyl, isolated from the $n$-butanol crude extract of $H$. indicum showed excellent wound-healing activity on H292 human lung cells [96]. The $n$-butanol extract of $H$. indicum also showed a significant wound-healing activity on $\mathrm{H} 292$ human lung cells in vitro [96]. Another experiment proved that the methanol and aqueous extracts of $H$. indicum revealed significant wound-healing activities than the other extracts (e.g., petroleum ether and chloroform) in rats [37]. 
7.15. Gastroprotective Effect. The aqueous extract of the dried leaves of $H$. indicum showed a dose-dependent gastroprotective effect in indomethacin-induced $(80 \mathrm{mg} / \mathrm{kg}$ of body weight) gastric ulcer mucosa in rats [10]. Histological observations of the different components of the mucosa layer of the stomach evidenced normal morphological appearance in the $H$. indicum groups, whereas in the control group, significant erosions in the mucosa were observed. It was also supposed that this effect may be due to the presence of tannins, alkaloids, and saponins in the leaves of the plant that may induce the release of prostaglandins in gastric mucosa maintaining gastric microcirculation through mucus and bicarbonate production.

7.16. Diuretic Effect. The methanolic root extract of $H$. indicum at 200 and $400 \mathrm{mg} / \mathrm{kg}$ revealed a marked diuretic effect of the electrolyte loss ratio $\left(\mathrm{Na}^{+} / \mathrm{K}^{+}\right.$excretion ratio was 1.38 and 1.45 , respectively) as compared with the standard diuretic furosemide (1.37) in mice $[7,105]$.

7.17. Relaxant/Receptor Property. The ethanol (95\%) extract of the roots showed weak smooth muscle-relaxant activity on guinea pig ileum and rabbit duodenum [97]. Another study performed on isolated guinea pig ileum, rabbit jejunum, rat uterus, and rat anococcygeus preparations with several agonists, antagonists, and the aqueous plant extract showed a dose-dependent activity of the acetylcholine, methylcholine, carbamylcholine, nicotine, histamine, oxytocin, and plasma cholinesterase [98].

7.18. Antithrombotic Effects. Different extracts of $H$. indicum exhibited a potential lysis of clots and stabilizing activities of the membrane, which is why traditionally the leaves of $H$. indicum have been used as a remedy for thrombosis. The ethanol, petroleum ether, carbon tetrachloride, and chloroform extracts of $H$. indicum leaves showed 23.78, 35.40, 32.48 , and $18.95 \%$ clot lysis activity, respectively, in the blood of healthy male subjects [99]. In this study, streptokinase, used as a positive control, showed a $65.15 \%$ clot lysis activity. In another study, the methanolic extract of the whole plant showed mild-to-moderate thrombolytic activity at a concentration of $1.0 \mathrm{mg} / \mathrm{mL}$ protecting red blood cells against hypotonic and heat-induced hemolysis [88]. In addition, the carbon tetrachloride soluble fraction obtained from this extract showed a $41.47 \pm 1.12$ and $37.97 \pm 0.14 \%$ of red blood cell lysis induced by hypotonic solution and heat, respectively, while acetylsalicylic acid used as positive control showed 71.92 and $42.12 \%$ of lysis [88].

7.19. Larvicidal Activity. H. indicum is a potential plant for the control of Aedes aegypti, which is a potential vector of the dengue virus. Veerakumar et al. [106] suggested that $H$. indicum can be an ideal eco-friendly plant for the control of Anopheles stephensi and A. aegypti. The alcoholic extracts of $H$. indicum at different concentrations $(0.30,0.25,0.20$, $0.15,0.10,0.075,0.050$, and $0.025 \mathrm{mg} / \mathrm{mL}$ ) were found to act against the mosquito larvae of $A$. aegypti [100]. In this study, an inability to come to the surface, restlessness, loss of equilibrium, and finally the death of the larvae were observed with the treatment of $H$. indicum extracts. The results showed a mortality of $10 \%$ already in the lowest concentration of $0.025 \mathrm{mg} / \mathrm{mL}$, reaching $100 \%$ in the concentration of $0.25 \mathrm{mg} / \mathrm{mL}$. However, no positive control was used in the study, making it difficult to compare the real efficacy of the extract.

7.20. Miscellaneous Effects. The aqueous and ethanol extracts of the $H$. indicum roots exhibited a strong uterine stimulant effect in rats [107]. Bero et al. [103] reported that the aqueous extract of $H$. indicum possesses antileukemic and ganglionblocking activities. The leaf extract of $H$. indicum is also evident to be used in ophthalmic disorders, erysipelas, and pharyngodynia [108]. An aqueous whole plant extract of $H$. indicum (30-300 mg/kg of body weight) exhibited an antiallergic effect on Dunkin-Hartley guinea pigs possibly by immunomodulation pathway [90].

7.21. Toxicological Profile. The aqueous and ethanolic extracts of the whole plant exhibited cumulative toxic effects on the kidney, liver, and lungs on prolonged use [82,101]. Heliotrine is evident to cause liver damage in experimental animals [109], while lasiocarpine developed malignant tumors in rats [110]. Retrorsine exerted a toxic effect on human embryo liver cells [111].

In a five-month toxicity study, an oral administration of the ethanol extract of $H$. indicum caused dose-dependent mortality $\left(\mathrm{LD}_{50}: 9.78 \mathrm{~g} / \mathrm{kg}\right.$ of body weight) in Swiss albino mice [112].

Pyrrolizidine alkaloids are evident to produce highly reactive adducts, such as 2,3-dihydro- $1 \mathrm{H}$-pyrrolizine protein, through the hepatic cytochrome P450 system. These adducts bind to proteins and genetic materials (e.g., DNA and RNA) and induce veno-occlusive disease in the liver [113]. The acute intoxication of pyrrolizidine alkaloids is characterized by hemorrhagic necrosis, hepatomegaly, and ascites, while chronic exposure is characterized by necrosis, fibrosis, cirrhosis, liver failure, and even death [114]. Due to photosensitization in animals upon their consumption and metabolism, pyrrolizidine alkaloids may initiate skin cancer [115]. Moreover, these substances can cause neurotoxicity and encephalitis, which is characterized by vertigo, headaches, delirium, and loss of consciousness [116].

\section{Discussion}

$H$. indicum has long been used in traditional medicine systems to treat various ailments; therefore, this review summarized the botany, traditional uses, phytochemistry, and pharmacology of this plant and its components. A number of phytochemical classes have been isolated from this medicinal plant. Available pharmacological studies on the ingredients and crude extracts indicated broad biological effects of $H$. indicum, providing basic evidence for traditional claims. However, as viewed from the current findings, some areas still require scientific evaluation and exploration. 
First, the leaves of $H$. indicum are the main medicinal part used in Bangladesh, while in other countries (e.g., India and Thailand), different parts are used for different purposes. Therefore, it is convenient to investigate the differences between plant parts regarding phytochemistry and pharmacology. Second, alkaloids are considered as the main bioactive constituents, particularly heliotrine and heleurine $\mathrm{N}$-oxide. Numerous bioactivities of other bioactive constituents have been reported to be of prominent pharmacological activities and are worth to be given more attention. In addition, more research on the identification and isolation can be done on extracts, with reported bioactivities to discover new active phytochemicals and elucidate their structure-activity relationships and possible synergistic effects. Third, the reliability of the herb to treat coronary heart disease, kidney diseases, hemorrhagic diseases, and vitiligo has been justified by the long history, but current findings are not enough to ascertain these traditional claims from the perspective of modern pharmacology. Moreover, the evaluation of representative and appropriate cell or animal models is equally important to assess these traditional uses precisely. Fourth, the anticancer activity of $\mathrm{H}$. indicum indicated that the plant could be a natural source to find promising and cost-effective lead compounds with little side effects for cancer treatment. The cytotoxic effects are mainly due to the action of the pyrrolizidine alkaloid, indicine $N$ oxide, which alters the assembly of tubulin into microtubules, inducing DNA damage [117]. However, the appearance of liver toxicity and even bone marrow aplasia has led to the withdrawal of this compound from the development of clinical trials $[118,119]$. Thus, it will be necessary to find new compounds in $H$. indicum with anticancer potential. Finally, acute and chronic toxicity should be comprehensively studied in order to establish safety and toxicological limits and provide guidance for clinical applications.

Phytochemical research has led to the isolation and identification of 32 compounds in $H$. indicum $[13,22]$. Different classes of compounds have been detected, including alkaloids, triterpenes, sterols, amines, and volatile oils (Table 3 and Figure 2). H. indicum contains a large class of alkaloids with antiinflammatory, analgesic, antibacterial, antitumor, and other activities. Among them, acetyl indicine, echinitine, heleurine, heliotrine, indicine, indicinine, indicine $\mathrm{N}$-oxide, lasiocarpine, retronecine, supinine, and trachelanthamidine were isolated from the aerial parts of the plant, while cynoglossine, europine $N$-oxide, heleurine $N$-oxide, and heliotridine $N$-oxide were separated from the seed, and heliotrine and lycopsamine were separated from the root $[30,53,62,67,69,71,73,75,76]$. The chemical structures of alkaloids are shown in Figure 2. Indicine $N$-oxide, which is the principal pyrrolizidine alkaloid isolated from $H$. indicum, has the potential risk of hepatotoxicity [104], and because of the presence of a high amount of pyrrolizidine alkaloids, this plant exerts potent anticancer activity [94]. The plasma cholinesterase receptor activity of $H$. indicum validates some of its traditional folk values such as relieving abdominal pain, hypertension, and impotence and sexual weakness [98].
Triterpenes are the second class of molecules that have been well-studied in $H$. indicum evidencing a wide variety of biological functions. Among them, $\beta$-amyrin, lupeol, and rapanone have been evidenced to possess biological functions, including defense against herbivores, microbial attack, or other sources of injury $[71,77]$. $\beta$-Amyrin also showed potential antihyperglycemic and hypolipidemic effects, suggesting that it could be a lead compound for drug development for diabetes and atherosclerosis [120]. Lupeol is a novel antiinflammatory and anticancer dietary triterpene, which has strong antioxidant, antimutagenic, antiinflammatory, and antiarthritic characteristics with potential pharmaceutical applications [121]. Rapanone has been reported to exert significant antioxidant, antiinflammatory, and cytotoxic activities against a panel of human tumor cells [122]. Toxicity studies have observed some alterations in rats such as tremor, ataxia, increased respiratory rate, and decreased activity at concentrations of $\beta$-amyrin above $30 \mathrm{mg} /$ $\mathrm{kg}$ for 4 weeks, while no toxicity has been observed for lupeol at doses up to $200 \mathrm{mg} / \mathrm{kg}[121,123]$. Although no significant effects of rapanone have been shown in non-cancer cells, at doses of 60 and $120 \mathrm{mg} / \mathrm{kg}$, it induced anovulatory effects in female mice $[124,125]$.

Six main sterol compounds have been isolated from $H$. indicum: $\beta$-sitosterol, chalinasterol, campesterol, stigmasterol, hexacosane-1-ol, and estradiol [77, 78]. Sterols have a wide variety of functions in plant physiology, including the regulation of $\mathrm{Na}^{+} / \mathrm{K}^{+}$-ATPase, cell differentiation, and proliferation or membrane fluidity and permeability [126-128]. In addition, plant-derived sterols have been reported to exert antiinflammatory effects useful in the treatment of non-alcoholic fatty liver, inflammatory bowel diseases, and allergic asthma [129]. However, no studies have specifically evaluated the effects of sterols isolated from $H$. indicum against these diseases.

Amines are an important class of molecules in $H$. indicum that display pesticidal, fungicidal, herbicidal, analgesic, and antioxidant activities. Putrescine, spermidine, and spermine were separated from the leaves of $H$. indicum [76]. Putrescine scavenges reactive oxygen species and regulates DNA and protein synthesis, cell proliferation, and differentiation of tissues, thereby supporting placental development and embryogenesis in mammals [130]. Spermidine is a polyamine compound that counteracts aging and promotes cellular longevity [131]. The compound induces autophagy in a mammalian target of rapamycin (mTOR) independent manner by inhibiting the acetyltransferase EP300, resulting in hypoacetylation of several core autophagy proteins, including ATG5, ATG7, ATG12, and LC3 [132]. Spermine is a natural polyamine known to be essential regulators of various cellular processes, including DNA stability, cellular growth, differentiation, and apoptosis, and also used to treat cancer, other pathologies, inflammation, immunity, infection, and aging [133].

Three volatile oils were separated from the whole plant of H. indicum [79]. Among them, linalool (acyclic monoterpene alcohol) exerted its antiproliferative activity against various cancer cells through the mevalonate pathway [134]. Linalool has nutraceutical anticancer, antioxidant, 
antimicrobial, antidiabetic, antinociceptive, antiinflammatory, and hypolipidemic effects [135]. Phytol, diterpene alcohol, inhibits the inflammatory response by reducing cytokine production and oxidative stress and also provides antinociceptive activities [136, 137], and it has many biomedical applications [138, 139], including antimicrobial, cytotoxic, anticancer, non-mutagenic, antiteratogenic, antibioticchemotherapeutic, antidiabetic, lipid-lowering, antispasmodic, anticonvulsant, antinociceptive, antioxidant, antiinflammatory, anxiolytic, antidepressant, immune-adjuvant, hair growth facilitator, hair fall defense, and antidandruff activities [140]. Moreover, it has antipyretic [141] and clot lysis activities [142].

Diabetes mellitus is a chronic metabolic disease caused by an absolute or relative lack of insulin and/or reduced physiological insulin activity, resulted in hyperglycemia and abnormalities in carbohydrate, protein, and fat metabolism [143]. The methanol extract of $H$. indicum showed a dosedependent antidiabetic effect on STZ-induced diabetic rats [89]. Different compounds present in this herb, for example, lupeol [144], phytol [140], and stigmasterol [145], have been found to show antidiabetic effects in experimental animals.

Rapanone has cytotoxic effects on MCF-7 cells, where it induced apoptosis through mitochondrial membrane potential loss [146]. Although effective therapeutic interventions are yet to be found out, it has been seen that estradiol positively impacts some aspects of cognitive function in humans and other animals [147]. Stigmasterol also possesses many biological activities, including immune-modulatory [148], anticancer [149], neuroprotective [150], hypolipidemic [151], and other effects. Putrescine has antiaging property [152] and can reduce antibiotic-induced oxidative stress in Burkholderia cenocepacia [153]. Spermidine alleviated autoimmune encephalomyelitis by inducing inhibitory macrophages [154]. It has several important biological activities, including antioxidant [155], cardioprotective, [156], neuroprotective [157], and other effects.

Spermine is a polyamine, initially discovered as crystals in human semen by Antonie van Leeuwenhoek in 1678 [158], and evokes olfactory responses in teleost fish [159] and possibly humans [160]. In a study, it has been found to act as a specific semen-derived sex pheromone in sea lamprey and promotes mating behaviors [161]. It is also evident to show antiinflammatory [162], mitochondrial protein synthesis [163], cardioprotective [164], and other effects. Lycopsamine exerted protective effects in spinal cord injury in rats by improving functional recovery and suppressing apoptosis [165]. Lupeol, a triterpene, found in this plant has several bioactivities, including antidiabetic, antiinflammatory, antioxidant [166, 167], skin protective [168], anticancer [149], and so on.

\section{Conclusion and Future Directions}

Medicinal plants and traditional medicine comprise about $90 \%$ of newly discovered pharmaceuticals, thus ensuring the safety, quality, and effectiveness of medicinal plants and herbal drugs that have gained much attention nowadays $[169,170]$. Numerous results of experiments developed by researchers around the world support the biological activities associated with the traditional uses of $H$. indicum. In this sense, it can be concluded that H. indicum is a potential source of chemical compounds with promising biological activities. However, nowadays, clinical trials are scarce, which makes it difficult to translate them into routine clinical practice, making it necessary to carry out additional studies. In addition, several pyrrolizidine alkaloids isolated from the plant have been evident to show hepatotoxic effects on experimental animals; hence, further studies are required to ensure the safety of internal use of this plant. We hope that the information provided here could be helpful for the safe traditional uses and beneficial for further research.

The use of plant extracts in experimentation involves many drawbacks, including changes in their constituents depending on the climate or form of cultivation, presence of compounds with adverse or antagonistic effects, or changes in bioactivity during their handling, storage, or preparation of materials. Thus, working with pure compounds with known bioactivity makes it possible to obtain a targeted therapeutic effect and determine effective doses, toxic doses, and selectivity indexes to control the quality of the therapeutic formulation [171]. In addition, working with isolated compounds will reduce the risk of infections in the plant that could end up affecting patients and the presence of contaminants such as heavy metals [172].

Loss of medicinal plant species over time is another challenge for us. Among 80,000 flowering plant species that are used for pharmaceutical purposes, about 15,000 species are exposed to a risk of extinction due to high harvesting and destruction of habitats [173], and $20 \%$ of their wildlife resources are decreasing due to growing human populations and excessive consumption of plants [174]. Thus, the environmental code of ethics should be strictly followed to preserve the biodiversity of medicinal plants [175]. The good agricultural practice may be helpful for the production and quality assurance of medicinal plants [176]. For example, China has promoted the growth of conventional medicinal plants [177].

Nowadays, many people believe that using herbal medicines is good for health, but there are still many concerns about its safety and efficacy. The ethnobotanical record of $H$. indicum indicates that this plant is used in many countries around the world for various diseases. Upon going through the scientific reports on this plant, it should be claimed that $H$. indicum contains many important phytochemicals and possesses diverse biological activities, suggesting it as an important medicinal plant. More studies are necessary on its phytochemical analysis. Furthermore, the biological activities evaluated on its phytoconstituents are not sufficient. Although $H$. indicum can potentially contribute to the advancement of health care, to date, only a few studies have been conducted on its isolated constituents, limiting its translation to clinical practice. Another factor that hinders its clinical use is the presence of some components, such as heliotrine, lasiocarpine, and retrorsine, with evidence of toxic effects on experimental animals or humanderived cells. In addition, to build credibility for the use of this medicinal plant in conventional medicine, the empirical 
arguments should be converted into evidence-based arguments. Finally, several issues about safety, effective dosing, treatment duration, side or adverse effects, acute and chronic toxicities, as well as the standardization of $H$. indicum herbal preparations and phytoconstituent products should be resolved properly by conducting adequate research on this hopeful medicinal plant. If these issues are properly resolved, this medicinal plant can be used as a safe, effective, and affordable form of health care.

\section{Abbreviations}

AA: $\quad$ Ascorbic acid

BHT: $\quad$ Butylated hydroxytoluene

DPPH: 1-Diphenyl-2 picrylhydrazyl

EC $_{50}$ : Half-maximal effective concentration

GC-FID: Gas chromatography-flame ionization detector

GC-MS: Gas chromatography-mass spectrometry

$\mathrm{IC}_{50}$ : Half-maximal inhibitory concentration

LPS: $\quad$ Lipopolysaccharide

MIC: Minimum inhibitory concentration

mTOR: Mammalian target of rapamycin

NMR: Nuclear magnetic resonance

RBC: $\quad$ Red blood cell

STZ: $\quad$ Streptozotocin

VO: $\quad$ Vocal order

WHO: World Health Organization.

\section{Conflicts of Interest}

The authors declare no conflicts of interest.

\section{Acknowledgments}

This work was supported by CONICYT PIA/APOYO CCTE AFB170007. A. Sureda was granted by the Instituto de Salud Carlos III (CIBEROBN CB12/03/30038).

\section{References}

[1] P. K. Mukherjee, P. Venkatesh, and S. Ponnusankar, "Ethnopharmacology and integrative medicine-let the history tell the future," Journal of Ayurveda and Integrative Medicine, vol. 1, no. 2, pp. 100-109, 2010.

[2] J. B. Calixto, A. R. Santos, V. Cechinel Filho, and R. A. Yunes, "A review of the plants of the genus Phyllanthus: their chemistry, pharmacology, and therapeutic potential," $\mathrm{Me}$ dicinal Research Reviews, vol. 18, no. 4, pp. 225-258, 1998.

[3] M. Sharifi-Rad, C. Lankatillake, D. A. Dias et al., "Impact of natural compounds on neurodegenerative disorders: from preclinical to pharmacotherapeutics," Journal of Clinical Medicine, vol. 9, no. 4, p. 1061, 2020.

[4] D. S. Fabricant and N. R. Farnsworth, "The value of plants used in traditional medicine for drug discovery," Environmental Health Perspectives, vol. 109, no. 1, pp. 69-75, 2001.

[5] B. Salehi, D. Calina, A. O. Docea et al., "Curcumin's nanomedicine formulations for therapeutic application in neurological diseases," Journal of Clinical Medicine, vol. 9, no. 2, p. 430, 2020.

[6] S. Oluwatoyin, G. I. Ndukwe, and A. Joseph, "Phytochemical and antimicrobial studies on the aerial parts of Heliotropium indicum Linn," Annals of Biological Research, vol. 2, no. 2, pp. 129-136, 2011.

[7] M. A. Rahman, M. Mia, and I. Shahid, "Pharmacological and phytochemical screen activities of roots of Heliotropium indicum Linn," PharmacologyOnLine, vol. 1, no. 1, pp. 185-192, 2011.

[8] M. O. Osungunna and K. A. Adedeji, "Phytochemical and antimicrobial screening of methanol extract of Heliotropium indicum leaf," Journal of Microbiology and Antimicrobials, vol. 3, no. 8, pp. 213-216, 2016.

[9] A. Togola, D. Diallo, S. Dembélé, H. Barsett, and B. S. Paulsen, "Ethnopharmacological survey of different uses of seven medicinal plants from Mali, (West Africa) in the regions Doila, Kolokani and Siby," Journal of Ethnobiology and Ethnomedicine, vol. 1, p. 7, 2005.

[10] A. A. Adelaja, M. D. Ayoola, J. O. Otulana, O. B. Akinola, A. Olayiwola, and A. B. Ejiwunmi, "Evaluation of the histo gastroprotective and antimicrobial activities of Heliotropium indicum Linn (boraginaceae)," Malaysian Journal of Medical Sciences, vol. 15, no. 3, pp. 22-30, 2008.

[11] M. Ayyanar and S. Ignacimuthu, "Herbal medicines for wound healing among tribal people in Southern India: ethnobotanical and scientific evidences," International Journal of Applied Research in Natural Products, vol. 2, no. 3, pp. 29-42, 2009.

[12] A. H. Nawaz, M. Hossain, M. Karim, M. Khan, R. Jahan, and M. Rahmatullah, "An ethnobotanical survey of Rajshahi district in Rajshahi division, Bangladesh," American-Eurasian Journal of Sustainable Agriculture, vol. 3, no. 2, pp. 143-150, 2009.

[13] G. K. Dash and M. S. Abdullah, "A review on Heliotropium indicum L. (Boraginaceae)," International Journal of Pharmaceutical Sciences and Research, vol. 4, no. 4, p. 1253, 2012.

[14] J. Chunthorng-Orn, B. Dechayont, P. Phuaklee, O. Prajuabjinda, T. Juckmeta, and A. Itharat, "Cytotoxic, anti-inflammatory and antioxidant activities of Heliotropium indicum extracts," Journal of the Medical Association of Thailand, vol. 99, no. 4, pp. S102-S109, 2016.

[15] M. Kugelman, W. C. Liu, M. Axelrod, T. J. McBride, and K. V. Rao, "Indicine- $N$-oxide: the antitumor principle of Heliotropium indicum," Lloydia, vol. 39, no. 2-3, pp. 125-128, 2015.

[16] R. Schoental, "Toxicology and carcinogenic action of pyrrolizidine alkaloids," Cancer Research, vol. 28, no. 11, pp. 2237-2246, 1968.

[17] T. Hartmann and D. Ober, Biosynthesis and Metabolism of Pyrrolizidine Alkaloids in Plants and Specialized Insect Herbivores, Springer, Berlin, Heidelberg, Germany, 2000.

[18] K. Srinivas, M. E. B. Rao, and S. Rao, "Anti-inflammatory activity of Heliotropium indicum Linn and Leucas aspera Spreng. in albino rats," Indian Journal of Pharmacology, vol. 32, no. 1, pp. 37-38, 2000.

[19] J. S. Reddy, P. R. Rao, and M. S. Reddy, "Wound healing effects of Heliotropium indicum, Plumbago zeylanicum and Acalypha indica in rats," Journal of Ethnopharmacology, vol. 79, no. 2, pp. 249-251, 2002.

[20] V. T. Veda, K. S. Sasi, B. R. Asokan, S. Sengottuvelu, and S. Jaikumar, "Anticataract activity of ethanolic extract of Heliotropium indicum leaves on galactose induced cataract in rats," International Journal of Pharmacology \& Toxicology, vol. 5, pp. 18-20, 2016.

[21] N. Kandemir, A. Çelik, S. N. Shah, and A. Razzaq, "Comparative micro-anatomical investigation of genus 
Heliotropium (Boraginaceae) found in Turkey," Flora, vol. 262, Article ID 151495, 2020.

[22] P. Ghosh, P. Das, C. Das, S. Mahapatra, and S. Chatterjee, "Morphological characteristics and phytopharmacological detailing of hatishur (Heliotropium indicum Linn.): a concise review," Journal of Pharmacognosy and Phytochemistry, vol. 7, no. 5, pp. 1900-1907, 2018.

[23] V. Reyes-García, "The relevance of traditional knowledge systems for ethnopharmacological research: theoretical and methodological contributions," Journal of Ethnobiology and Ethnomedicine, vol. 6, p. 32, 2010.

[24] M. F. Nisar, F. Jaleel, M. Waseem, S. Ismail, Y. Toor, and S. Mujtaba Haider, "Ethno-medicinal uses of plants from district Bahawalpur, Pakistan," Current Research Journal of Biological Sciences, vol. 6, no. 5, pp. 183-190, 2014.

[25] Z. Kamal, J. Bairage, Moniruzzaman et al., "Ethnomedicinal practices of a folk medicinal practitioner in Pabna district, Bangladesh," World Journal of Pharmacy and Pharmaceutical Sciences, vol. 3, no. 12, pp. 73-85, 2014.

[26] S. Shahnaj, U. Asha, T. Mim et al., "A survey on the ethnomedicinal practices of a folk medicinal practitioner in Manikganj district, Bangladesh," Journal of Chemical and Pharmaceutical Research, vol. 7, no. 8, pp. 690-696, 2015.

[27] J. Akhter, R. Khatun, S. Akter et al., "Ethnomedicinal practices in Natore district, Bangladesh," World Journal of Pharmacy and Pharmaceutical Sciences, vol. 5, no. 8, pp. 212-222, 2021.

[28] C. Muthu, M. Ayyanar, N. Raja, and S. Ignacimuthu, "Medicinal plants used by traditional healers in Kancheepuram district of Tamil Nadu, India," Journal of Ethnobiology and Ethnomedicine, vol. 2, p. 43, 2006.

[29] C. Alagesaboopathi, "Ethnomedicinal plants and their utilization by villagers in Kumaragiri hills of Salem district of Tamilnadu, India," African Journal of Traditional, Complementary and Alternative Medicines, vol. 6, no. 3, pp. 222-227, 2009.

[30] C. Wiart, Medicinal Plants of the Asia-Pacific, CRC Press, Boca Raton, FL, USA, 2006.

[31] T. O. Odugbemi, O. R. Akinsulire, I. E. Aibinu, and P. O. Fabeku, "Medicinal plants useful for malaria therapy in Okeigbo, Ondo state, Southwest Nigeria," African Journal of Traditional, Complementary and Alternative Medicines, vol. 4, no. 2, pp. 191-198, 2007.

[32] S. Suroowan, K. B. Pynee, and M. F. Mahomoodally, "A comprehensive review of ethnopharmacologically important medicinal plant species from Mauritius," South African Journal of Botany, vol. 122, pp. 189-213, 2019.

[33] J. Berhaut, "Flore illustrée du Sénégal," Gouvernement du Sénégal, Ministère du développement rural, Direction des eaux et forêts, vol. 9.

[34] K. L. Dey, The Indigenous Drugs of India, Thacker, Spink, \& Co., Calcutta, India, 1896.

[35] R. N. Chopra, S. L. Nayar, I. C. Chopra et al., Glossary of Indian Medicinal Plants, Council of Scientific \& Industrial Research, New Delhi, India, 1956.

[36] S. A. Dahanukar, R. A. Kulkarni, and N. N. Rege, "Pharmacology of medicinal plants and natural products," Indian Journal of Pharmacology, vol. 32, no. 4, pp. S81-S118, 2000.

[37] G. K. Dash and P. N. Murthy, "Studies on wound healing activity of Heliotropium indicum Linn. leaves on rats," ISRN Pharmacology, vol. 2011, Article ID 847980, 2011.

[38] E. Adjanohoun, "Le processus de rénovation de la pharmacopée africaine," Bulletin de la Société Botanique de
France Actualités Botaniques, vol. 136, no. 3-4, pp. 35-39, 2014.

[39] R. Apema, D. Mozouloua, E. Kosh-Komba, and Y. Ngoule, "Les plantes médicinales utilisées dans le traitement de l'hypertension artérielle par les tradipraticiens à Bangui,".

[40] K. Kalanda and W. D. Omasombo, "Contribution à la connaissance des plantes médicinales du Haut Zaïre: plantes utilisées dans le traitement des maux d'estomac dans la ville de Kisangani," Revue de Médecine et de Pharmacie, vol. 9, no. 1, pp. 59-69, 2019.

[41] S. Agudelo-Lopez, L. Gomez-Rodriguez, X. Coronado et al., "[Prevalence of intestinal parasitism and associated factors in a village on the Colombian Atlantic Coast]," Revista de Salud Pública, vol. 10, no. 4, pp. 633-642, 2008.

[42] M. Carrière, "Plantes de Guinée à l'usage des éleveurs et des vétérinaires. Annexes.” CIRAD-EMVT.

[43] F. B. Magassouba, A. Diallo, M. Kouyate et al., "Ethnobotanical survey and antibacterial activity of some plants used in Guinean traditional medicine," Journal of Ethnopharmacology, vol. 114, no. 1, pp. 44-53, 2007.

[44] G. Komlaga, C. Agyare, R. A. Dickson et al., "Medicinal plants and finished marketed herbal products used in the treatment of malaria in the Ashanti region, Ghana," Journal of Ethnopharmacology, vol. 172, pp. 333-346, 2015.

[45] R. Walker, "Usages pharmaceutiques des plantes spontanées du Gabon," Institut d'Études Centrafricaines, vol. 4, no. 6, pp. 232-262, 1986.

[46] A. K. Das, B. K. Dutta, and G. D. Sharma, "Medicinal plants used by different tribes of Cachar district, Assam," Indian Journal of Traditional Knowledge, vol. 7, no. 3, pp. 446-454, 2008.

[47] A. Bouquet, "Plantes médicinales de la Côte d'Ivoire," ORSTOM, vol. 165, pp. 38-39, 1974.

[48] G. F. Asprey and P. Thornton, "Medicinal plants of Jamaica. Parts III," West Indian Medical Journal, vol. 4, no. 4, pp. 69-82, 1955.

[49] C. Daruty, Plantes médicinales de I'lle Maurice et des pays intertropicaux, Mauritius Stationery and Printing Establishment, Mauritius, 2018.

[50] H. Nordeng, W. Al-Zayadi, D. Diallo, N. Ballo, and B. S. Paulsen, "Traditional medicine practitioners' knowledge and views on treatment of pregnant women in three regions of Mali," Journal of Ethnobiology and Ethnomedicine, vol. 9, no. 1, p. 67.

[51] J. R. Ainslie, The List of Plants Used in Native Medicine in Nigeria, Imp, vol. 7, Forest Inst Oxford Inst Paper.

[52] K. K. Ajibesin, B. A. Ekpo, D. N. Bala, E. E. Essien, and S. A. Adesanya, "Ethnobotanical survey of Akwa Ibom state of Nigeria," Journal of Ethnopharmacology, vol. 115, no. 3, pp. 387-408, 2008.

[53] F. G. Coe and G. J. Anderson, "Ethnobotany of the garifuna of Eastern Nicaragua," Economic Botany, vol. 50, no. 1, pp. 71-107, 1996.

[54] B. Barrett, "Medicinal plants of Nicaragua's atlantic coast," Economic Botany, vol. 48, no. 1, pp. 8-20, 1994.

[55] E. Quisumbing, "Medicinal plants of the Philippines," Tech Bull, vol. 16, p. 126.

[56] A. Gurib-Fakim, J. Gueho, and M. Sewraj-Bissoondoyal, "The medicinal plants of Mauritius-part 1," International Journal of Pharmacognosy, vol. 35, no. 4, pp. 237-254, 2008.

[57] A. K. Samoisy and M. F. Mahomoodally, "Ethnopharmacological analysis of medicinal plants used against non-communicable diseases in Rodrigues Island, Indian 
Ocean," Journal of Ethnopharmacology, vol. 173, pp. 20-38, 2015.

[58] E. J. Adjanohoun, A. Abel, L. Aké Assi et al., "Médecine traditionelle et pharmacopée-contribution aux études ethnobotaniques et floristiques aux Seychelles," Agence de Coopération Culturelle et Technique, Paris, France, p. 170.

[59] J. Kerharo and J. G. Adam, "La pharmacopée sénégalaise traditionnelle: plantes médicinales et toxiques," Editions Vigot Frères, vol. 1011, 1974.

[60] J. Berhault, "Floore Illustree du Senegal," Govt Senegal, Min Rural Development, Water and Forest Division, Dakar, vol. 2, pp. 110-114.

[61] V. Sequeira, "Medicinal plants and conservation in São Tomé," Biodiversity \& Conservation, vol. 3, no. 9, pp. 910-926.

[62] J. A. Duke, Amazonia Ethnobotanical Dictionary, CRC Press, Boca Raton, FL, USA, 1994.

[63] M. S. Kpodar, S. D. Karou, G. Katawa et al., "An ethnobotanical study of plants used to treat liver diseases in the maritime region of Togo," Journal of Ethnopharmacology, vol. 181, pp. 263-273, 2015.

[64] J. O. Kokwaro, "Medicinal plants of east Africa," East African Literature Bureau, p. 232, 1976.

[65] C. C. Lin and W. S. Kan, "Medicinal plants used for the treatment of hepatitis in Taiwan," The American Journal of Chinese Medicine, vol. 18, no. 1-2, pp. 35-43, 1990.

[66] E. S. Ayensu, Medicinal Plants of the West Indies, Reference Publications, Inc, Algonac, MI, USA, 1981.

[67] J. J. Williaman and B. G. Schubert, "Alkaloid-bearing plants and their contained alkaloids. Technical Bulletin No. 1234," Journal of Pharmaceutical Sciences, vol. 51, no. 3, p. 296, 1962.

[68] A. R. Mattocks, R. Schoental, H. C. Crowley, and C. C. J. Culvenor, "Indicine: the major alkaloid of Heliotropium indicum L," Journal of the Chemical Society, vol. 1961, pp. 5400-5403, 1961.

[69] M. S. Hoque, A. Ghani, and H. Rashid, "Alkaloids of Heliotropium indicum L. grown in Bangladesh," Bangladesh Pharmaceutical Journal, vol. 5, pp. 13-15, 1976.

[70] V. B. Pandey, J. P. Singh, Y. V. Rao, and S. B. Acharya, "Isolation and pharmacological action of heliotrine, the major alkaloid of Heliotropium indicum seeds," Planta Medica, vol. 45, no. 4, pp. 229-233, 1982.

[71] D. P. Pandey, J. P. Singh, R. Roy, V. P. Singh, and V. B. Pandey, "Constituents of Heliotropium indicum," Oriental Journal of Chemistry, vol. 12, pp. 321-322, 1996.

[72] S. Sivagnanam, M. K. Singh, M. K. Satish, and M. R. K. Rao, "Preliminary phytochemical analysis of Amaranthus polygonoides," Research Journal of Pharmaceutical, Biological, and Chemical Sciences, vol. 5, no. 3, p. 82, 2014.

[73] A. R. Mattocks, "Minor alkaloids of Heliotropium indicum L," Journal of the Chemical Society C: Organic, pp. 329-331, 1967.

[74] H. Birecka, M. W. Frohlich, and L. M. Glickman, "Free and esterified necines in Heliotropium species from Mexico and Texas," Phytochemistry, vol. 22, no. 5, pp. 1167-1171, 1983.

[75] J. S. N. Souza, L. L. Machado, O. D. L. Pessoa et al., "Pyrrolizidine alkaloids from Heliotropium indicum," Journal of the Brazilian Chemical Society, vol. 16, no. 6B, pp. 1410-1414, 2005.

[76] H. Birecka, T. E. DiNolfo, W. B. Martin, and M. W. Frohlich, "Polyamines and leaf senescence in pyrrolizidine alkaloidbearing Heliotropium plants," Phytochemistry, vol. 23, no. 5, pp. 991-997, 1984.
[77] C. K. Andhiwal, C. Has, and R. P. Varshney, "Chemical and pharmacological studies of Heliotropium indicum," Indian Drugs, vol. 22, no. 11, pp. 567-569, 2013.

[78] A. Mannan and K. Ahmad, "Preliminary study of sex hormones of medical importance in Bangladeshi plants," Bangladesh Medical Research Council Bulletin, vol. 4, no. 2, pp. 78-85, 1978.

[79] T. Machan, J. Korth, B. Liawruangrath, S. Liaewruangrath, and S. Pyne, "Composition and antituberculosis activity of the volatile oil of Heliotropium indicum Linn. growing in Phitsanulok, Thailand," Flavour and Fragrance Journal, vol. 21, no. 2, pp. 265-267, 2005.

[80] M. S. Kumar, S. Chaudhury, and S. Balachandran, "In vitro callus culture of Heliotropium indicum Linn. for assessment of total phenolic and flavonoid content and antioxidant activity," Applied Biochemistry and Biotechnology, vol. 174, no. 8, pp. 2897-2909, 2014.

[81] M. Kumar, S. Kumar, S. Balachandran, and S. Chaudhury, "Influence of incubation temperatures on total phenolic, flavonoids content and free radical scavenging activity of callus from Heliotropium indicum L," Asian Journal of Pharmaceutical Research, vol. 2, no. 4, pp. 2231-5683, 2012.

[82] A. Boye, G. A. Koffuor, P. Amoateng, E. O. Ameyaw, and A. K. Abaitey, "Analgesic activity and safety assessment of Heliotropium indicum Linn. (Boraginaceae) in rodents," International Journal of Pharmacology, vol. 8, no. 2, pp. 91-100, 2012.

[83] K. S. Betanabhatla, S. R. Jasmin, J. Raamamurthy, A. J. Christina, and S. Sasikumar, "Anti-inflammatory and anyinociceptive activities of Heliotropium indicum Linn. experimental animal models," PharmacologyOnLine, vol. 3, pp. 438-445, 2007.

[84] S. Shalini, R. Kaza, and F. Shaik, "Study on the antiinflammatory activity of Heliotropium indicum," Journal of Innovative Trends in Pharmaceutical Sciences, vol. 1, no. 1, p. 43, 2010.

[85] S. Kyei, G. A. Koffuor, P. Ramkissoon, E. O. Ameyaw, and E. A. Asiamah, "Anti-inflammatory effect of Heliotropium indicum Linn on lipopolysaccharide-induced uveitis in New Zealand white rabbits," International Journal of Ophthalmology, vol. 9, no. 4, pp. 528-535, 2016.

[86] P. R. Rao, S. Nammi, and A. D. V. Raju, "Studies on the antimicrobial activity of Heliotropium indicum Linn," Journal of Natural Remedies, vol. 2, no. 2, pp. 195-198, 2002.

[87] D. Premnath and P. Gomez, "Antifungal and anti bacterial activities of chemical constituents from Heliotropium indicum Linn. Plant," Drug Invention Today, vol. 4, no. 11, pp. 564-568, 2012.

[88] N. A. Mourin, T. Sharmin, S. R. Chowdhury, F. Islam, M. S. Rahman, and M. A. Rashid, "Evaluation of bioactivities of Heliotropium indicum, a medicinal plant of Bangladesh," Pharma Innovation, vol. 2, pp. 217-221, 2013.

[89] S. A. Mohammad, S. Abdul Nabi, S. Marella et al., "Phytochemical screening and antihyperglycemic activity of Heliotropium indicum whole plant in streptozotocin induced diabetic rats," Journal of Applied Pharmaceutical Science, vol. 4, no. 12, pp. 65-71, 2015.

[90] S. Kyei, G. A. Koffuor, P. Ramkissoon, C. Afari, and E. A. Asiamah, "The claim of anti-cataract potential of Heliotropium indicum: a myth or reality?" Ophthalmology and Therapy, vol. 4, no. 2, pp. 115-128, 2015.

[91] N. Goyal and S. Sharma, "Bioactive phytoconstituents and plant extracts from genus Heliotropium," International Journal of Green Pharmacy, vol. 8, no. 4, pp. 217-225, 2014. 
[92] R. V. Savadi, K. R. Alagawadi, and S. S. Darade, "Antifertility activity of ethanolic extract and its n-hexane and benzene fractions of Heliotropium indicum leaves on albino rats," Journal of Pharmacy Research, vol. 2, no. 5, pp. 927-930, 2009.

[93] K. Mahato, B. B. Kakoti, S. Borah, and M. Kumar, "Evaluation of in-vitro anthelmintic activity of Heliotropium indicum Linn. leaves in Indian adult earthworm," Asian Pacific Journal of Tropical Disease, vol. 4, pp. S259-S262, 2014.

[94] V. Sivajothi, D. S. Shruthi, and J. R. Sajini, "Cytotoxic effect of Heliotropium indicum extracts on Hela cell line," International Journal of Pharmacy and Pharmaceutical Sciences, vol. 7, no. 6, pp. 412-414, 2015.

[95] M. H. Villa, J. N. T. Peria, N. J. M. Mangansat, and R. M. R. Dulay, "Antitussive and antibacterial activity of Trompang elepante (Heliotropium indicum Linn.)," Asian Journal of Plant Science and Research, vol. 6, no. 1, pp. 30-34, 2016.

[96] Y. Dodehe, A. Barthelemy, B. Calixte, D. N. Jean, J. D. Allico, and F. Nelly, "In vitro wound healing effect of n-butanol fractions from Heliotropium indicum," Just-in-Time Production Systems, vol. 2, pp. 1-7, 2013.

[97] J. E. V. Vieira, G. S. G. Barros, M. C. Medeiros, F. J. A. Matos, M. P. Souza, and M. J. Medeiros, "Pharmacologic screening of plants from Northeast Brazil. II," Revista brasileira de farmácia, vol. 49, pp. 67-75, 1972.

[98] G. A. Koffuor, A. Boye, P. Amoateng, E. O. Ameyaw, and A. K. Abaitey, "Investigating the site of action of an aqueous extract of Heliotropium indicum Linn (Boraginaceae) on smooth muscles," Research Journal of Pharmacology, vol. 6, no. 1, pp. 12-19, 2012.

[99] K. Samira, F. R. Laboni, A. S. Julie, U. Jalal, and Z. K. Labu, "Biological investigations of medicinal plants of Heliotropium indicum indigenous to Bangladesh," Journal of Coastal Life Medicine, vol. 4, no. 11, pp. 874-878, 2016.

[100] V. Ramamurthy and S. Krishnaveni, "Larvicidal efficacy of leaf extracts of Heliotropium Indicum and Mukia maderaspatana against the dengue fever mosquito vector Aedes aegypti," Journal of Entomology and Zoology Studies, vol. 2, pp. 40-45, 2014.

[101] A. Roy, "Pharmacological activities of Indian Heliotrope (Heliotropium indicum L.): a review," Journal of Pharmacognosy and Phytochemistry, vol. 4, no. 3, pp. 101-104, 2015.

[102] L. F. Pianowski, J. B. Calixto, and C. P. Chaves, Pharmaceutical Oral Product Obtained from Parts of Heliotropium Plants, 2011.

[103] J. Bero, H. Ganfon, M. C. Jonville et al., "In vitro antiplasmodial activity of plants used in Benin in traditional medicine to treat malaria," Journal of Ethnopharmacology, vol. 122, no. 3, pp. 439-444, 2009.

[104] T. Ohnuma, K. S. Sridhar, L. H. Ratner, and J. F. Holland, "Phase I study of indicine $\mathrm{N}$-oxide in patients with advanced cancer," Cancer Treatment Reviews, vol. 66, no. 7, pp. 1509-1515, 1982.

[105] A. Bose, S. Mondal, J. Gupta, G. Dash, T. Ghosh, and S. Si, "Studies on diuretic and laxative activity of ethanolic extract and its fractions of Cleome rutidosperma aerial parts," Pharmacognosy Magazine, vol. 2, no. 7, pp. 178-182, 2006.

[106] K. Veerakumar, M. Govindarajan, M. Rajeswary, and U. Muthukumaran, "Mosquito larvicidal properties of silver nanoparticles synthesized using Heliotropium indicum (Boraginaceae) against Aedes aegypti, Anopheles stephensi, and Culex quinquefasciatus (Diptera: Culicidae)," Parasitology Research, vol. 113, no. 6, pp. 2363-2373, 2014.

[107] G. S. Barros, F. J. Matos, J. E. Vieira, M. P. Sousa, and M. C. Medeiros, "Pharmacological screening of some Brazilian plants," Journal of Pharmacy and Pharmacology, vol. 22, no. 2, pp. 116-122, 1970.

[108] D. Kumarasamyraja, N. S. Jeganathan, and R. Manavalan, “A review on medicinal plants with potential wound healing activity," International Journal of Pharmacy and Pharmaceutical Sciences, vol. 2, pp. 105-111, 2012.

[109] G. S. Christie and R. N. Le Page, "Liver damage in acute heliotrine poisoning. 1. The intracellular distribution of pyridine nucleotides," Biochemical Journal, vol. 84, no. 1, pp. 25-38, 1962.

[110] M. S. Rao and J. K. Reddy, "Malignant neoplasms in rats fed lasiocarpine," British Journal of Cancer, vol. 37, no. 2, pp. 289-293, 1978.

[111] S. J. Armstrong and A. J. Zuckerman, "The effects of lasiocarpine, retrorsine and retronecine pyrrole on human embryo lung and liver cells in culture," British Journal of Experimental Pathology, vol. 53, no. 2, pp. 138-144, 1972.

[112] M. A. Owolabi, O. O. Oribayo, G. E. Ukpo, G. O. Mbaka, and O. E. Akindehin, "A 5-month toxicity study of the ethanol extract of the leaves of Heliotropium indicum in Sprague Dawley rats after oral administration," Nigerian Quarterly Journal of Hospital Medicine, vol. 25, no. 3, pp. 184-192, 2015.

[113] A. R. Mattocks, "Toxicity of pyrrolizidine alkaloids," Nature, vol. 217 , no. 5130 , pp. 723-728, 1968.

[114] R. Moreira, D. M. Pereira, P. Valentao, and P. B. Andrade, "Pyrrolizidine alkaloids: chemistry, pharmacology, toxicology and food safety," International Journal of Molecular Sciences, vol. 19, no. 6, p. 1668, 2018.

[115] Y. Zhao, Q. Xia, J. J. Yin, G. Lin, and P. P. Fu, "Photoirradiation of dehydropyrrolizidine alkaloids--formation of reactive oxygen species and induction of lipid peroxidation," Toxicology Letters, vol. 205, no. 3, pp. 302-309, 2011.

[116] R. J. Huxtable, "Human health implications of pyrrolizidine alkaloids and herbs containing them," Toxicants of Plant Origin, vol. 1, pp. 41-86, 1989.

[117] P. Appadurai and K. Rathinasamy, "Indicine $\mathrm{N}$-oxide binds to tubulin at a distinct site and inhibits the assembly of microtubules: a mechanism for its cytotoxic activity," Toxicology Letters, vol. 225, no. 1, pp. 66-77, 2013.

[118] B. A. Cook, J. R. Sinnhuber, P. J. Thomas et al., "Hepatic failure secondary to indicine $\mathrm{N}$-oxide toxicity. A pediatric oncology group study," Cancer, vol. 52, no. 1, pp. 61-63, 1983.

[119] L. Letendre, J. Ludwig, J. Perrault, W. A. Smithson, and J. S. Kovach, "Hepatocellular toxicity during the treatment of refractory acute leukemia with indicine $\mathrm{N}$-oxide," Cancer, vol. 54, no. 7, pp. 1256-1259, 1984.

[120] F. A. Santos, J. T. Frota, B. R. Arruda et al., "Antihyperglycemic and hypolipidemic effects of alpha, betaamyrin, a triterpenoid mixture from Protium heptaphyllum in mice," Lipids in Health and Disease, vol. 11, p. 98, 2012.

[121] M. Saleem, "Lupeol, a novel anti-inflammatory and anticancer dietary triterpene," Cancer Letters, vol. 285, no. 2, pp. 109-115, 2009.

[122] G. L. Pardo Andreu, F. Z. D. Reis, M. González-Durruthy et al., "Rapanone, a naturally occurring benzoquinone, inhibits mitochondrial respiration and induces HepG2 cell death," Toxicology in Vitro, vol. 63, Article ID 104737, 2020. 
[123] A. Thirupathi, P. C. Silveira, R. T. Nesi, and R. A. Pinho, " $\beta$-Amyrin, a pentacyclic triterpene, exhibits anti-fibrotic, anti-inflammatory, and anti-apoptotic effects on dimethyl nitrosamine-induced hepatic fibrosis in male rats," Human \& Experimental Toxicology, vol. 36, no. 2, pp. 113-122, 2016.

[124] J. Calle, J. Olarte, R. Pinzon, L. F. Ospina, M. C. Mendoza, and M. J. Orozco, "Alterations in the reproduction of mice induced by rapanone," Journal of Ethnopharmacology, vol. 71, no. 3, pp. 521-525, 2000.

[125] D. Wróbel-Biedrawa, K. Grabowska, A. Galanty, D. Sobolewska, P. Żmudzki, and I. Podolak, "Anti-melanoma potential of two benzoquinone homologues embelin and rapanone-a comparative in vitro study," Toxicology in Vitro, vol. 65, Article ID 104826, 2020.

[126] M.-A. Hartmann, "5 Sterol metabolism and functions in higher plants," in Lipid Metabolism and Membrane Biogenesis, G. Daum, Ed., Springer, Berlin, Heidelberg, Germany, 2004.

[127] A. Ferrer, T. Altabella, M. Arro, and A. Boronat, "Emerging roles for conjugated sterols in plants," Progress in Lipid Research, vol. 67, pp. 27-37, 2017.

[128] W. Stillwell, An Introduction to Biological Membranes, Elsevier, Berlin, Heidelberg, Germany, 2nd edition, 2016.

[129] J. Plat, S. Baumgartner, T. Vanmierlo et al., "Plant-based sterols and stanols in health \& disease: consequences of human development in a plant-based environment?" Progress in Lipid Research, vol. 74, pp. 87-102, 2019.

[130] X. Wang, G. Wu, and F. W. Bazer, "mTOR: the master regulator of conceptus development in response to uterine histotroph during pregnancy in ungulates," in Molecules to Medicine with mTORAcademic Press, Cambridge, MA USA, 2016.

[131] N. Minois, P. Rockenfeller, T. K. Smith, and D. CarmonaGutierrez, "Spermidine feeding decreases age-related locomotor activity loss and induces changes in lipid composition," PLoS One, vol. 9, no. 7, Article ID e102435, 2014.

[132] M. O. J. Grootaert, A. Kurdi, D. G. De Munck, W. Martinet, and G. R. Y. De Meyer, "Autophagy in atherosclerosis," in Autophagy: Cancer, Other Pathologies, Inflammation, Immunity, Infection, and Aging, M. A. Hayat, Ed., Academic Press, Cambridge, MA, USA, 2016.

[133] S. Aliwaini, J. Bleloch, S. Kimani, and S. Prince, "Induction of autophagy and apoptosis in melanoma treated with palladacycle complexes," in Autophagy: Cancer, Other Pathologies, Inflammation, Immunity, Infection, and Aging, M. A. Hayat, Ed., Academic Press, Cambridge, MA, USA, 2016.

[134] H. M. Abdelaziz, M. S. Freag, and A. O. Elzoghby, "Solid lipid nanoparticle-based drug delivery for lung cancer," in Nanotechnology-Based Targeted Drug Delivery Systems for Lung Cancer, P. Kesharwani, Ed., Academic Press, Cambridge, MA, USA, 2019.

[135] M. H. Mughal, "Linalool: a mechanistic treatise," Journal of Nutrition, Food Research and Technology, vol. 2, no. 1, pp. 1-5, 2019.

[136] R. O. Silva, F. B. Sousa, S. R. Damasceno et al., "Phytol, a diterpene alcohol, inhibits the inflammatory response by reducing cytokine production and oxidative stress," Fundamental \& Clinical Pharmacology, vol. 28, no. 4, pp. 455-464, 2014.

[137] C. C. Santos, M. S. Salvadori, V. G. Mota et al., "Antinociceptive and antioxidant activities of phytol in vivo and in vitro models," Journal of Neuroscience, vol. 2013, Article ID 949452, 2013.
[138] M. Alencar, M. T. Islam, E. S. Ali et al., “Association of phytol with toxic and cytotoxic activities in an antitumoral perspective: a meta-analysis and systemic review," Anti-Cancer Agents in Medicinal Chemistry, vol. 18, no. 13, pp.1828-1837, 2018.

[139] M. T. Islam, E. S. Ali, S. J. Uddin et al., "Phytol: a review of biomedical activities," Food and Chemical Toxicology, vol. 121, pp. 82-94, 2018.

[140] M. T. Islam, M. V. de Alencar, K. da Conceicao Machado et al., "Phytol in a pharma-medico-stance," Chemico-Biological Interactions, vol. 240, pp. 60-73, 2015.

[141] M. T. Islam, "Antipyretic effect of phytol, possibly via 5KIRdependent COX-2 inhibition pathway," Inflammopharmacology, vol. 27, no. 4, pp. 857-862, 2019.

[142] M. T. Islam, S. Molla, A. K. Das, F. Zaman, and R. Khan, "In vitro anti-atherothrombosis activity of Nigella sativa oil, phytol and their combinations," Indian Journal of Pharmaceutical Education and Research, vol. 53, no. 4, pp. 670674, 2019.

[143] M. Blair, "Diabetes mellitus review," Urologic Nursing, vol. 36, no. 1, pp. 27-36, 2016.

[144] W. J. Hashmi, H. Ismail, F. Mehmood, and B. Mirza, "Neuroprotective, antidiabetic and antioxidant effect of Hedera nepalensis and lupeol against $\mathrm{STZ}+\mathrm{AlCl} 3$ induced rats model," Daru, vol. 26, no. 2, pp. 179-190, 2018.

[145] J. Wang, M. Huang, J. Yang et al., "Anti-diabetic activity of stigmasterol from soybean oil by targeting the GLUT4 glucose transporter," Food \& Nutrition Research, vol. 61, no. 1, Article ID 1364117, 2017.

[146] V. Kuete, L. K. Omosa, V. R. Tala et al., "Cytotoxicity of plumbagin, rapanone and 12 other naturally occurring quinones from Kenyan flora towards human carcinoma cells," BMC Pharmacology and Toxicology, vol. 17, no. 1, p. 60, 2016.

[147] G. Le, S. A. Novotny, T. L. Mader et al., "A moderate oestradiol level enhances neutrophil number and activity in muscle after traumatic injury but strength recovery is accelerated," The Journal of Physiology, vol. 596, no. 19, pp. 4665-4680, 2018.

[148] A. O. Antwi, D. D. Obiri, N. Osafo, L. B. Essel, A. D. Forkuo, and C. Atobiga, "Stigmasterol alleviates cutaneous allergic responses in rodents," BioMed Research International, vol. 2018, Article ID 3984068, 2018.

[149] T. Kangsamaksin, S. Chaithongyot, C. Wootthichairangsan, R. Hanchaina, C. Tangshewinsirikul, and J. Svasti, "Lupeol and stigmasterol suppress tumor angiogenesis and inhibit cholangiocarcinoma growth in mice via downregulation of tumor necrosis factor-alpha," PLoS One, vol. 12, no. 12, Article ID e0189628, 2017.

[150] O. E. Adebiyi, J. O. Olopade, and F. O. Olayemi, "Sodium metavanadate induced cognitive decline, behavioral impairments, oxidative stress and down regulation of myelin basic protein in mice hippocampus: ameliorative roles of beta-spinasterol, and stigmasterol," Brain and Behavior, vol. 8, no. 7, Article ID e01014, 2018.

[151] C. H. Zhao, C. Zhao, H. Q. Ye et al., "Hypolipidemic activity of low-cholesterol ovum oil of Rana chensinensis and phytosterol (stigmasterol) in rats," Journal of Zhejiang University Science B, vol. 20, no. 7, pp. 613-616, 2019.

[152] W. Xu, L. Li, J. Sun et al., "Putrescine delays postovulatory aging of mouse oocytes by upregulating PDK4 expression and improving mitochondrial activity," Aging, vol. 10, no. 12, pp. 4093-4106, 2018. 
[153] O. M. El-Halfawy and M. A. Valvano, "Putrescine reduces antibiotic-induced oxidative stress as a mechanism of modulation of antibiotic resistance in Burkholderia cenocepacia," Antimicrobial Agents and Chemotherapy, vol. 58, no. 7, pp. 4162-4171, 2014.

[154] Q. Yang, C. Zheng, J. Cao et al., "Spermidine alleviates experimental autoimmune encephalomyelitis through inducing inhibitory macrophages," Cell Death \& Differentiation, vol. 23, no. 11, pp. 1850-1861, 2016.

[155] K. Ohashi, M. Kageyama, K. Shinomiya et al., "Spermidine oxidation-mediated degeneration of retinal pigment epithelium in rats," Oxidative Medicine and Cellular Longevity, vol. 2017, Article ID 4128061, 2017.

[156] T. Eisenberg, M. Abdellatif, S. Schroeder et al., "Cardioprotection and lifespan extension by the natural polyamine spermidine," Nature Medicine, vol. 22, no. 12, pp. 1428-1438, 2016.

[157] Y. Yang, S. Chen, Y. Zhang et al., "Induction of autophagy by spermidine is neuroprotective via inhibition of caspase 3mediated beclin 1 cleavage," Cell Death \& Disease, vol. 8, no. 4, p. e2738, 2017.

[158] C. W. Tabor and H. Tabor, "Polyamines," Annual Review of Biochemistry, vol. 53, no. 1, pp. 749-790, 1984.

[159] S. H. Rolen, P. W. Sorensen, D. Mattson, and J. Caprio, "Polyamines as olfactory stimuli in the goldfish Carassius auratus," The Journal of Experimental Biology, vol. 206, no. 10, pp. 1683-1696, 2003.

[160] P. L. Lefevre, M. F. Palin, and B. D. Murphy, "Polyamines on the reproductive landscape," Endocrine Reviews, vol. 32, no. 5 , pp. $694-712$.

[161] A. M. Scott, Z. Zhang, L. Jia et al., "Spermine in semen of male sea lamprey acts as a sex pheromone," PLoS Biology, vol. 17, no. 7, Article ID e3000332, 2019.

[162] M. Zhang, T. Caragine, H. Wang et al., "Spermine inhibits proinflammatory cytokine synthesis in human mononuclear cells: a counterregulatory mechanism that restrains the immune response," Journal of Experimental Medicine, vol. 185, no. 10, pp. 1759-1768, 1997.

[163] B. E. Christian, M. E. Haque, and L. L. Spremulli, "The effect of spermine on the initiation of mitochondrial protein synthesis," Biochemical and Biophysical Research Communications, vol. 391, no. 1, pp. 942-946, 2010.

[164] C. Wei, H. Li, Y. Wang et al., "Exogenous spermine inhibits hypoxia/ischemia-induced myocardial apoptosis via regulation of mitochondrial permeability transition pore and associated pathways," Experimental Biology and Medicine, vol. 241, no. 14, pp. 1505-1515, 2016.

[165] J. Jin, H. Li, G. Zhao, and S. Jiang, "Lycopsamine exerts protective effects and improves functional outcome after spinal cord injury in rats by suppressing cell death," Medical Science Monitor: International Medical Journal of Experimental and Clinical Research, vol. 24, pp. 7444-7450, 2018.

[166] T. Geetha and P. Varalakshmi, "Anti-inflammatory activity of lupeol and lupeol linoleate in rats," Journal of Ethnopharmacology, vol. 76, no. 1, pp. 77-80, 2001.

[167] S. Prasad, N. Kalra, and Y. Shukla, "Hepatoprotective effects of lupeol and mango pulp extract of carcinogen induced alteration in Swiss albino mice," Molecular Nutrition \& Food Research, vol. 51, no. 3, pp. 352-359, 2007.

[168] M. Malinowska, B. Miroslaw, E. Sikora et al., "New lupeol esters as active substances in the treatment of skin damage," PLoS One, vol. 14, no. 3, Article ID e0214216, 2019.
[169] F. Jamshidi-Kia, Z. Lorigooini, and H. Amini-Khoei, "Medicinal plants: past history and future perspective," Journal of Herbmed Pharmacology, vol. 7, no. 1, pp. 1-7, 2018.

[170] S. D. Sarker and L. Nahar, Chemistry for Pharmacy Students: General, Organic, and Natural Product Chemistry, John Wiley Sons Inc, Hoboken, NJ, USA, 2007.

[171] H. Zhang, "Bioactive natural products: detection, isolation, and structural determination," Phytomedicine, vol. 18, no. 10, pp. 902-903, 2008.

[172] A. M. Clark, "Natural products as a resource for new drugs," Pharmaceutical Research, vol. 13, no. 8, pp. 1133-1141, 1996.

[173] R. E. Bentley, Medicinal Plants, Domville-Fife Press, London, UK, 2018.

[174] I. A. Ross, Constituents, Medicinal Plants of the World (Volume 3): Chemical Traditional and Modern Medicinal Uses, Humana Press, Totowa, NJ, USA, 1999.

[175] S.-Y. Pan, S.-F. Zhou, S.-H. Gao et al., "New perspectives on how to discover drugs from herbal medicines: CAM's outstanding contribution to modern therapeutics," EvidenceBased Complementary and Alternative Medicine, vol. 2013, Article ID 627375, 2013.

[176] K. Chan, D. Shaw, M. S. Simmonds et al., "Good practice in reviewing and publishing studies on herbal medicine, with special emphasis on traditional Chinese medicine and Chinese materia medica," Journal of Ethnopharmacology, vol. 140, no. 3, pp. 469-475, 2012.

[177] J. Ma, K. Rong, and K. Cheng, "Research and practice on biodiversity in situ conservation in China: pro-gress and prospect," Biodiversity Science, vol. 20, no. 5, pp. 551-558, 2012. 